\title{
Somatostatin Inhibits Thalamic Network Oscillations In Vitro: Actions on the GABAergic Neurons of the Reticular Nucleus
}

\author{
Qian-Quan Sun, John R. Huguenard, and David A. Prince \\ Department of Neurology and Neurological Science, Stanford School of Medicine, Stanford, California 94305
}

\begin{abstract}
We examined the effects of somatostatin (SST) on neurons in the thalamic reticular nucleus (RT) using whole-cell patchclamp techniques applied to visualized neurons in rat thalamic slices. SST, acting via sst $_{5}$ receptors and pertussis toxinsensitive G-proteins, activated an inwardly rectifying $\mathrm{K}^{+}$(GIRK) current in 20 of 28 recorded cells to increase input conductance $15 \pm 3 \%$ above control and inhibited $\mathrm{N}$-type $\mathrm{Ca}^{2+}$ currents in 17 of 24 neurons via voltage-dependent mechanisms. SST reversibly depressed evoked EPSCs (eEPSCs) to $37 \pm 8 \%$ of control without altering their kinetics. SST-mediated inhibition of eEPSCs showed short-term relief from block during $25 \mathrm{~Hz}$ stimulus trains. SST also reduced the frequency $(33 \pm 8 \%)$ but not the amplitude of miniature EPSCs (mEPSCs). These data indicate that SST mediates presynaptic inhibition of glutamate release onto RT neurons. In current-clamp recordings, SST preferentially inhibited burst discharges mediated by near-
\end{abstract}

The thalamocortical network underlies major brain rhythms activated during sleep, wakefulness, and dreaming (Llinas and Ribary, 1993; Steriade et al., 1993) and during 3-4 Hz spike-wave discharge (SWD) as seen in absence seizures (Williams, 1953; Prince and Farrell, 1969; Steriade and Llinas, 1988; von Krosigk et al., 1993; Huguenard and Prince, 1994) (for review, see Huguenard and Prince, 1997). It has been shown that classical neurotransmitters such as norepinephrine, released from neurons in the brainstem, suppress the generation of synchronized activities and promote sensory processing by depolarizing neurons of thalamic reticular and relay nuclei (McCormick and Prince, 1987, 1988). Anatomical studies have demonstrated abundant peptidergic projections into mammalian thalamus; however, very little is known about the physiological roles of these inputs, with the exception of cholecystokinin (CCK) (Cox et al., 1995, 1997). Unlike classical neurotransmitters, release of neuropeptides is generally thought to depend on high-frequency neuronal discharges $(5-40 \mathrm{~Hz})$ (Jan and Jan, 1982; Cropper et al., 1990; Wagner et al., 1993; Weisskopf et al., 1993; Williams and Johnston, 1996). Thus peptides may be preferentially released from neurons during certain forms of rhythmic oscillations or elevated neuronal activity (Vezzani et al., 1999), such as occur in

\footnotetext{
Received Oct. 9, 2001; revised April 1, 2002; accepted April 3, 2002.

This work was supported by National Institute of Neurological Disorders and Stroke Research Grant NS12151 and the Pimley Research and Training Funds. We are grateful to Isabel Parada for excellent assistance in the immunocytochemistry experiments, and Dr. Zhe Lu (Department of Physiology, University of Pennsylvania) for the generous gift of tertiapin-Q.

Correspondence should be addressed to John R. Huguenard, Department of Neurology and Neurological Sciences, Stanford University School of Medicine, Stanford CA 94305. E-mail: john.huguenard@stanford.edu.

Copyright (ㄷ) 2002 Society for Neuroscience 0270-6474/02/225374-13\$15.00/0
}

threshold corticothalamic EPSPs and intracellularly applied depolarizing currents. SST had powerful effects on in vitro intrathalamic rhythms, which included a shortening of the duration and a reduction in spike count within each oscillatory event. Furthermore, there was a paradoxical increase in the synchrony of epileptiform oscillations, likely mediated by a suppression of the responses to weak synaptic inputs in RT. We conclude that SST suppresses discharges in RT neurons, via presynaptic inhibition of glutamate release and postsynaptic activation of GIRK channels, leading to the dampening of both spindle-like and epileptiform thalamic network oscillations. SST may act as an important endogenous regulator of physiological and pathological thalamocortical network activities.

Key words: somatostatin; EPSCs; GIRK channels; $\mathrm{CA}^{2+}$ channels; neural network; epilepsy

absence seizures and spindle waves within the thalamocortical circuit.

Somatostatin (SST) is a peptide neurotransmitter present in the terminals of inhibitory interneurons in many brain regions, including cortex (Kawaguchi and Kubota, 1996; Chow et al., 1999), hippocampus (Buckmaster and Jongen-Relo, 1999), and striatum (Kubota and Kawaguchi, 2000). In human, primate, cat, and mouse thalamus, SST is colocalized with the inhibitory neurotransmitter GABA in neurons of the thalamic reticular nucleus (RT) that project to thalamocortical relay cells (Graybiel and Elde, 1983; Bendotti et al., 1990; Burgunder and Young, 1992). SST activates five distinct G-protein-coupled receptors ( sst $_{1-5}$ ) (Hoyer et al., 1995), which are widely expressed in the mammalian CNS (Dournaud et al., 1996; Stroh et al., 1999). SST has been linked to many complex brain functions (Matsuoka et al., 1991) and CNS disorders such as Alzheimer's (Epelbaum, 1986) and Huntington's diseases (Epelbaum, 1986). Studies in hippocampus suggest that a loss of SSTergic interneurons occurs in epilepsy (Sloviter, 1987; Buckmaster and Jongen-Relo, 1999). Recent immunocytochemical studies in rat indicate a high level of sst $_{5}$ receptor expression in RT with lower levels of other SST receptor subtypes in this and other thalamic nuclei (Dournaud et al., 1996; Stroh et al., 1999). SST has recently been shown to suppress GABA release from terminals of RT neurons (Leresche et al., 2000). These findings are of particular interest, because RT provides major GABAergic inputs to thalamocortical neurons and is a key structure in the generation of intrathalamic oscillations and the spike-wave discharge (SWD) of absence seizures (von Krosigk et al., 1993; Huguenard and Prince, 1994; Huntsman et al., 1999). We examined the effects of exogenous activation of SST receptors on RT cells and on network oscillations elicited in an in vitro thalamic slice preparation. 


\section{MATERIALS AND METHODS}

Slice preparation. All experiments were performed using a protocol approved by the Stanford Institutional Animal Care and Use Committee. Young Sprague Dawley rats $[10-16$ d old (P10-16)] were deeply anesthetized with pentobarbital sodium $(55 \mathrm{mg} / \mathrm{kg})$ and decapitated. The brains were quickly removed and placed into cold $\left(\sim 4^{\circ} \mathrm{C}\right)$ oxygenated slicing medium containing (in $\mathrm{mM}$ ): $2.5 \mathrm{KCl}, 1.25 \mathrm{NaH}_{2} \mathrm{PO}_{4}, 10.0 \mathrm{MgCl}_{2}$, $0.5 \mathrm{CaCl}_{2}, 26.0 \mathrm{NaHCO}_{3}, 11.0$ glucose, and 234.0 sucrose. Tissue slices $(300-400 \mu \mathrm{m})$ were cut in the horizontal plane using a Vibratome (TPI, St. Louis, MO), transferred to a holding chamber, and incubated $\left(35^{\circ} \mathrm{C}\right)$ for at least $1 \mathrm{hr}$ before recording. Individual slices were then transferred to a recording chamber fixed to a modified microscope stage and allowed to equilibrate for at least $30 \mathrm{~min}$ before recording. Slices were minimally submerged and continuously superfused with oxygenated physiological saline at $4.0 \mathrm{ml} / \mathrm{min}$. Recordings of G-protein-coupled inward rectifier potassium (GIRK) currents were obtained at $35 \pm 1{ }^{\circ} \mathrm{C}$, whereas $\mathrm{Ca}^{2+}$ currents were recorded at room temperature $\left(23^{\circ} \mathrm{C}\right)$. The physiological perfusion solution contained (in $\mathrm{mM}$ ): $126.0 \mathrm{NaCl}, 2.5 \mathrm{KCl}, 1.25$ $\mathrm{NaH}_{2} \mathrm{PO}_{4}, 2.0 \mathrm{MgCl}_{2}, 2.0 \mathrm{CaCl}_{2}, 26.0 \mathrm{NaHCO}_{3}$, and 10.0 glucose. These solutions were gassed with $95 \% \mathrm{O}_{2} / 5 \% \mathrm{CO}_{2}$ to a final $\mathrm{pH}$ of 7.4.

Whole-cell patch-clamp recording. Whole-cell recordings were obtained using visualized slice patch techniques (Edwards et al., 1989) and a modified microscope (Zeiss Axioskop) with a fixed stage. A low-power objective $(2.5 \times)$ was used to identify the various thalamic nuclei, and a high-power water immersion objective $(40 \times)$ with Nomarski optics and infrared video was used to visualize individual neurons.

Recording pipettes were fabricated from capillary glass obtained from World Precision Instruments (M1B150F-4), using a Sutter Instrument P80 puller, and had tip resistances of $2-5 \mathrm{M} \Omega$ when filled with the intracellular solutions below. An Axopatch1A amplifier (Axon Instruments, Foster City, CA) was used for voltage and current-clamp recordings. Access resistance in whole-cell recordings ranged from 4 to $12 \mathrm{M} \Omega$, and $50-75 \%$ of this was electronically compensated. Current and voltage protocols were generated using PCLAMP software (Axon Instruments). The following software packages were used for data analysis: Clampfit, PStat (Axon Instruments), SCAN (courtesy of J. Dempster, Strathclyde), Winplot (courtesy of N. Dale, St. Andrews University), Origin (Microcal), and locally written programs, Metatape and Detector (J. R. Huguenard).

For recordings of network oscillations (multiunit extracellular and current clamp, e.g., see Figs. 9, 11), the physiological perfusion solution listed above was used, but with $1.2 \mathrm{~mm} \mathrm{MgCl}_{2}$. For recording and isolation of $\mathrm{Ca}^{2+}$ currents in thalamic slices, the external solution was composed of (in $\mathrm{mM}$ ): $120 \mathrm{NaCl}, 20$ tetraethylammonium chloride (TEACl), $3 \mathrm{KCl}, 2.5 \mathrm{CaCl}_{2}, 2 \mathrm{MgCl}_{2}$, $10 \mathrm{HEPES}, 5 \mathrm{CsCl}, 14$-aminopyridine (4-AP), and $1 \mu \mathrm{M}$ tetrodotoxin (TTX), $\mathrm{pH} 7.3$, osmolarity adjusted to $292 \mathrm{mOsm} / \mathrm{l}$. This solution was gassed with $100 \% \mathrm{O}_{2}$. The pipette solution contained (in $\mathrm{mm}$ ): $117 \mathrm{Cs}$-gluconate, $13 \mathrm{KCl}, 1.0$ $\mathrm{MgCl}_{2}, 0.07 \mathrm{CaCl}_{2}, 0.1$ EGTA, 10.0 HEPES, 10 TEACl, $2.0 \mathrm{Na}_{2}$-ATP, and $0.4 \mathrm{Na}-\mathrm{GTP}, \mathrm{pH} \mathrm{7.4}$, osmolarity adjusted to $280 \mathrm{mOsm} / 1$. For recording and isolation of GIRK currents, the physiological perfusion solution contained (in $\mathrm{mm}$ ): $98.5 \mathrm{NaCl}, 30 \mathrm{KCl}, 1.25 \mathrm{NaH}_{2} \mathrm{PO}_{4}, 2.0$ $\mathrm{MgSO}_{4}, 2.0 \mathrm{CaCl}_{2}, 26.0 \mathrm{NaHCO}_{3}$, and 10.0 glucose. This solution was gassed with $95 \% \mathrm{O}_{2}$ and $5 \% \mathrm{CO}_{2}$ to a final $\mathrm{pH}$ of 7.4. Pipette saline was modified according to Sodickson and Bean (1996) and was composed of (in mM): $100 \mathrm{~K}$-gluconate, $13 \mathrm{KCl}, 9 \mathrm{MgCl}_{2}, 0.07 \mathrm{CaCl}_{2}, 10 \mathrm{EGTA}, 10.0$ HEPES, $2.0 \mathrm{Na}_{2}$-ATP, and $0.4 \mathrm{Na}-\mathrm{GTP}$, $\mathrm{pH}$ adjusted to 7.4 and osmolarity adjusted to $280 \mathrm{mOsm} / \mathrm{l}$. This solution was also used as pipette saline for current-clamp recordings.

Network oscillations. Extracellular multiple-unit activities were recorded using monopolar tungsten electrodes (0.2-2 M $\Omega$; Frederick Haer, Brunswick, ME) and a Grass amplifier (bandwidth, $0.3-3 \mathrm{kHz}$ ). All data were digitized $(1-2 \mathrm{kHz}$ ) and stored using Axotape software (Axon Instruments). Bipolar extracellular stimuli were delivered through sharpened tungsten electrodes.

A software Schmidt trigger was used to detect spikes. The "duration" of an oscillation was measured as the time from stimulus to last spike burst. Bursts were defined as four spikes occurring within $50 \mathrm{msec}$. The "total spike activity" of an oscillation was defined as the number of spikes occurring between the time of the stimulus and the end of the recording sweep. To quantify the degree of synchrony and the duration of the intrathalamic oscillations, autocorrelograms were constructed from the extracelluar multiple-unit data, typically with a bin size of 5-10 msec. Results from five consecutive oscillations were summed for each plot. The oscillatory activity in the autocorrelograms was quantified by three measures: time constant of oscillation decay, an indication of duration as measured by the rate of fall-off from the central to the satellite peaks; oscillatory index (OI), a normalized measure of synchrony estimated from ratio of the first anti-peak (valley) and peak amplitudes (a valley to peak ratio of 0 would be completely synchronous and would have an $\mathrm{OI}$ of $100 \%$ ); and finally the interpeak interval, or period, which is indicative of the main frequency component of the oscillation (cf. Cox et al., 1997; Huntsman et al., 1999).

Immunocytochemistry. P15 rats were deeply anesthetized with sodium pentobarbital and perfused through the heart with $100 \mathrm{ml}$ of $0.1 \mathrm{M}$ PBS $0.9 \%, \mathrm{pH}=7.4$, followed by $300 \mathrm{ml}$ of $4 \%$ paraformaldehyde in $0.1 \mathrm{M}$ phosphate buffer. The brains were removed and postfixed for $1 \mathrm{hr}$ in the same fixative and then sectioned at $35 \mu \mathrm{m}$ with the Vibratome. Sections were blocked in $10 \%$ normal goat serum and then incubated for $16 \mathrm{hr}$ in

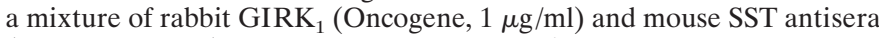
(Chemicon, 1:30) diluted in PBS and $0.2 \%$ Triton X-100. After the sections were rinsed in PBS, they were incubated in a mixture of Alexa goat anti-rabbit Texas Red and Alexa goat anti-mouse fluorescein (Chemicon; $5 \mu \mathrm{g} / \mathrm{ml}$ each) for $2 \mathrm{hr}$. Sections were mounted on slides and coverslipped using Vectashield mounting media (Vector Labs). Double immunofluorescence was assessed with a laser confocal microscope (model 2010; Molecular Dynamics).

Drugs. Drugs were applied focally through a multibarrel microperfusion pipette that was positioned within $1 \mathrm{~mm}$ of the cell. SST analogs were made as follows. Concentrated SST (Peninsula Labs, Belmont, CA) stock solutions were dissolved in ultra-pure water to a final concentration of $0.1 \mathrm{M}$ and stored in a $-70^{\circ} \mathrm{C}$ freezer. Stock SST solutions were diluted in physiological saline to final concentrations of $100 \mathrm{nM}$ to $0.5 \mu \mathrm{M} 1 \mathrm{hr}$ before use. Unless noted otherwise, a concentration of $100 \mathrm{~nm}$ was used. Concentrated cyclo-SST (Peninsula Labs), BIM23052 (D-Phe-Phe-PheD-Trp-Lys-Thr-Phe-Thr-NH2), nc8-12 [D-Phe-c(Cys-Tyr-D-Trp-LysAbu-Phe), locally synthesized], and octreotide (D-Phe-Cys-Phe-DTrpLys-Thr-Cys-Thr-ol; American Peptide, Sunnyvale, CA) solutions were also stored at $-70^{\circ} \mathrm{C}$. Aliquots were diluted to a final concentration in physiological solution just before use and applied via multibarrel focal perfusion. GTP- $\gamma-\mathrm{S}$, GDP- $\beta$-S, and pertussis toxin were purchased from Sigma (St. Louis, MO). The following ion channel blockers were used: bicuculline methiodide (BMI; Sigma), $\omega$-agatoxin-TK (Sigma), $\omega$-conotoxin-GVIA ( $\omega$-CgTx-GVIA, Sigma), CsCl (Sigma), TEACl (GFS Chemicals, Columbus, OH), TTX (Sigma), ZD7288 (Tocris, Ballwin, MO), and tertiapin-Q (gift of Dr. Zhe Lu, Department of Physiology, University of Pennsylvania, Philadelphia, PA).

Statistics. All data are presented as mean \pm SEM unless stated otherwise. Analysis by Student's $t$ test was performed for paired and unpaired observations unless stated otherwise. $p$ values of $<0.05$ were considered statistically significant.

\section{RESULTS}

As reported previously, $\mathrm{GIRK}_{1}$ immunoreactivity was heterogeneously distributed in the thalamus with moderate labeling in reticular nucleus (Fig. $1 A 1)$ and more intense staining in the relay neurons of the dorsal thalamus (Fig. 1A1) (cf. Ponce et al., 1996). For these studies we compared RT with the adjacent ventrobasal

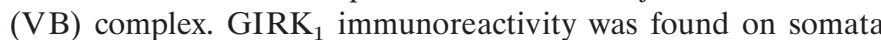
and dendrites in both $\mathrm{VB}$ and reticular neurons (Fig. 1A1,B, small white arrows). By contrast, SST immunoreactivity was not detected in somatodendritic regions but only found in linearly distributed puncta, presumably along fibers, in both VB and RT (Fig. 1A2). SST-immunoreactive puncta were much more prominent in the reticular nucleus than VB (Fig. 1A2,B, large red arrows), suggesting an important role of SST in regulating the function of RT neurons. High-magnification images showed that these SST-immunoreactive fibers were closely associated with somata and dendrites of GIRK $_{1}$-immunoreactive neurons in both VB and RT (Fig. 1B, large red arrows).

\section{SST activation of $\mathrm{K}^{+}$currents in RT neurons}

RT neurons, visually identified in slices and recorded with wholecell techniques, had characteristic electrophysiological features (Huguenard and Prince, 1994), including brief action potentials 

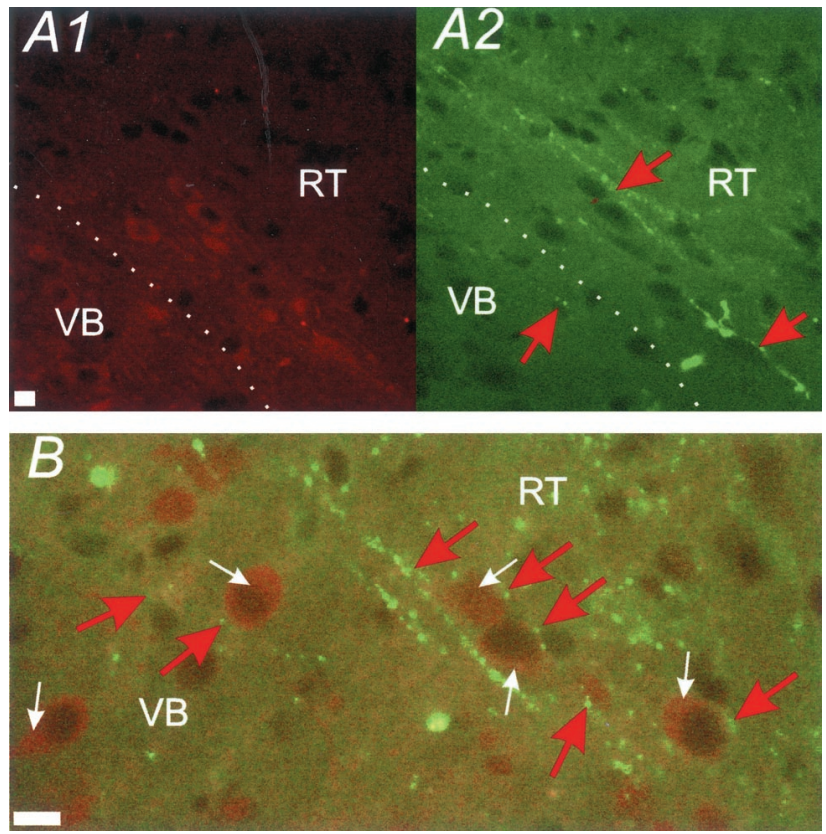

Figure 1. Photomicrographs showing localization of GIRK $_{1}$ and SST immunoreactivity (IR) in rat thalamic slices. $A$, Confocal laser scan image of a thalamic slice showing $\operatorname{GIRK}_{1}$-IR $(A 1$, red $)$ and SST-IR $(A 2$, green) in the reticular $(R T)$ and adjacent ventrobasal $(V B)$ nucleus. Dotted line in $A 1$ and $A 2$ demarcates the border between RT and VB. B, Superimposed images from $A 1$ and $A 2$ showing SST-immunopositive puncta (green pixel clusters indicated by large red arrows, also in $A 2$ ) and adjacent $\mathrm{GIRK}_{1}$ immunopositive somata (B, small white arrows). Scale bars, $10 \mu \mathrm{m}$.

and high-frequency burst discharges (Figs. 2A, 8A1,B1,C1,D, $9 A 2, B 1-2)$. The effects of SST on $\mathrm{K}^{+}$currents were examined using voltage-ramp commands from -130 to $-50 \mathrm{mV}$. SST (100$500 \mathrm{~nm}$ ) increased the magnitude of the ramp-evoked current responses in the majority (20 of 28) (Fig. 2B1) of neurons, indicating that the effects of SST were mediated through an increase in membrane conductance. The ramp current amplitude in the remaining neurons was either unaffected (5 of 28) or reduced ( 3 of 28) by SST, suggesting a closing of $\mathrm{K}^{+}$channels and a decrease in membrane conductance in some cells. The SSTmediated activation of $\mathrm{K}^{+}$channels in $\mathrm{RT}$ produced a $0.8 \pm 0.1$ $\mathrm{nS}$ conductance change, when measured at a membrane potential near rest $(-70$ to $-50 \mathrm{mV})$. This represented an increase of $15 \pm$ $3 \%$ above baseline input conductance $(5.2 \pm 0.2 \mathrm{nS})$, measured in the same way.

The $\mathrm{K}^{+}$selectivity of the SST-sensitive currents was studied by examining their reversal potential and overall conductance in perfusates containing different $\left[\mathrm{K}^{+}\right]_{\mathrm{o}}$ concentrations. Reversal potentials examined in $2.5 \mathrm{~mm}\left[\mathrm{~K}^{+}\right]_{\mathrm{o}}[-98 \pm 4 \mathrm{mV}$ vs $-99 \mathrm{mV}$ theoretical value (cf. Sodickson and Bean,1996); $n=20]$ and 30 $\mathrm{mm}\left[\mathrm{K}^{+}\right]_{\mathrm{o}},(-45 \pm 3 \mathrm{vs}-48 \mathrm{mV}$ theoretical value; $n=7)$ agreed well with those calculated from the Nernst equation for potassium. The relative conductance was larger when $\left[\mathrm{K}^{+}\right]_{\mathrm{o}}$ was increased to $30 \mathrm{~mm}(250 \pm 45 \%$ increase; $n=7)$, a finding consistent with previous studies of GIRK currents (Sodickson and Bean, 1996). Thus the SST-induced current was highly $\mathrm{K}^{+}$ selective.

The effects of SST on $\mathrm{K}^{+}$currents were assessed in one series of experiments in a perfusate containing $30 \mathrm{~mm}\left[\mathrm{~K}^{+}\right]_{\mathrm{o}}$ to maximize the GIRK current responses, and TTX $(1 \mu \mathrm{M})$ and $\mathrm{Cd}^{2+}$ $(200 \mu \mathrm{M})$ to block inward voltage-gated $\mathrm{Na}^{+}$and $\mathrm{Ca}^{2+}$ currents
A1
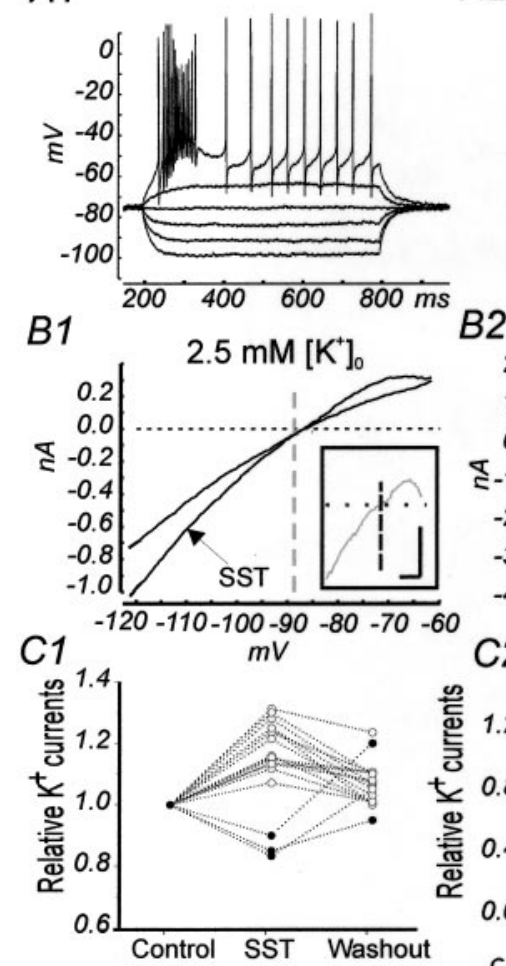

B2
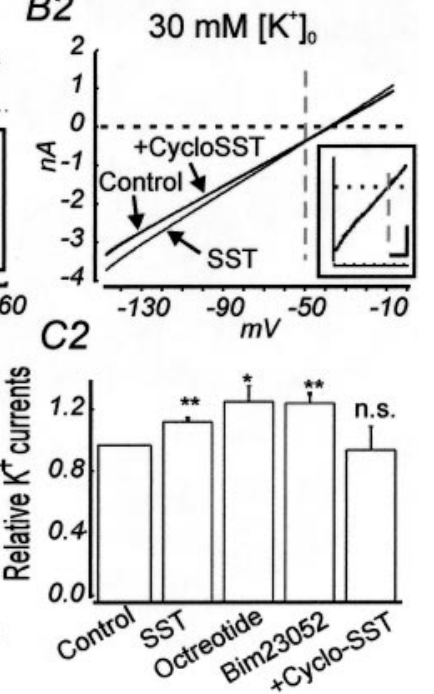

Figure 2. SST activates $\mathrm{K}^{+}$-selective currents in $\mathrm{RT}$ neurons. $A 1$, Current-clamp recording showing typical responses of an RT neuron to a series of current steps ranging from -150 to $+100 \mathrm{pA}$. $A 2$, Currents elicited in a voltage-clamped RT neuron by voltage ramps $(-120$ to -60 $\mathrm{mV}$, over $1 \mathrm{sec}$ ) from a holding potential of $-50 \mathrm{mV}$ (holding current: $-100 \mathrm{pA} ; 30 \mathrm{~mm}\left[\mathrm{~K}^{+}\right]_{\text {out }}$ ) before, during, and after application of $500 \mathrm{nM}$ SST application. $B$, Currents elicited by voltage ramps in an RT neuron in the absence (control and wash averaged) and presence of $500 \mathrm{~nm} \mathrm{SST} \mathrm{in}$ $2.5 \mathrm{~mm}(B 1)$ and $30 \mathrm{~mm}\left[\mathrm{~K}^{+}\right]_{\text {out }}$ (B2). Superimposed traces in B2 also show the lack of effect of $100 \mathrm{~nm}$ Cyclo-SST on $\mathrm{K}^{+}$currents. Each current trace was averaged from 10 consecutive responses. Horizontal dashed lines in insets: 0 pA. Vertical dashed lines in each panel show expected $\mathrm{K}^{+}$dependent reversal potentials for SST-evoked responses with $\left[\mathrm{K}^{+}\right]_{\text {in }}=$ $113 \mathrm{~mm}$. Insets, SST-sensitive currents obtained by subtracting normalized control [(control + wash)/2] from SST traces. Calibration: B1 inset, 10 $\mathrm{mV}, 150 \mathrm{pA} ; B 2$ inset, $30 \mathrm{mV}, 300 \mathrm{pA}$. Vertical dashed lines in $B 1$ and $B 2$ insets indicate reversal potential of -87 and $-50 \mathrm{mV}$, respectively. $C 1$, Normalized current amplitude at $-130 \mathrm{mV}$ with $30 \mathrm{~mm}\left[\mathrm{~K}^{+}\right]_{\text {out }}$ in control solution and during SST (100 nM) application and washout in 17 RT neurons. In this and the following figures, relative $\mathrm{K}^{+}$current indicates the ratio of the holding currents at $-130 \mathrm{mV}$ in drug (e.g., SST, $\mathrm{Ba}^{2+}$, etc.) and control conditions. Dashed lines connect control and +SST responses for each cell. $\bullet$, Inhibition; $\bigcirc$, enhancement. $C 2$, Mean $\mathrm{K}^{+}$ current in control solution and after perfusion of SST $\left(n=28 ;{ }^{* *} p<0.01\right.$ vs control), $100 \mathrm{~nm}$ octreotide ( $n=6 ; p<0.05$ vs control), $100 \mathrm{nM}$ $\operatorname{Bim} 23052\left(n=5 ;{ }^{* *} p<0.01\right.$ vs control), or SST + Cyclo-SST $(n=6$; not significant vs control).

and outward $\mathrm{Ca}^{2+}$-activated $\mathrm{K}^{+}$currents. Under these conditions $100 \mathrm{~nm}$ SST increased conductance in 7 of 11 RT cells (Fig. $2 A 2, B 2)$. In the majority of cells tested, the current-voltage plot of SST-sensitive current in RT neurons in both $2.5 \mathrm{~mm}$ (15 of 20) and $30 \mathrm{mM} \mathrm{K}^{+}$(4 of 7) demonstrated inward rectification (Fig. $2 B 1)$. In the remaining cells, SST-sensitive currents were more linear (Fig. 2B2). These properties are similar to those reported previously for baclofen- or neuropeptide Y (NPY)-elicited GIRK currents in rat thalamic neurons (Sun et al., 2001a,b). 


\section{SST activation or inhibition of $\mathrm{K}^{+}$currents in VB neurons}

For comparison we also examined the effects of SST on GIRK current in VB neurons. Interestingly, $100 \mathrm{~nm}$ SST inhibited $\mathrm{K}^{+}$ currents in 25 of $41 \mathrm{VB}$ neurons and activated or had no effect on them in 16 of $41 \mathrm{VB}$ cells. The SST-induced change in input conductance in the former group of VB cells was $-0.6 \pm 0.1 \mathrm{nS}$, which amounted to a $12 \pm 2 \%$ decrease. These results suggest that SST differentially regulates $\mathrm{K}^{+}$currents in $\mathrm{RT}$ and VB neurons.

\section{The effects of SST on $\mathrm{K}^{+}$currents in RT neurons are predominantly mediated by sst $_{5}$ receptors}

To identify the SST receptors involved in modulation of $\mathrm{K}^{+}$ currents in RT neurons, we applied selective agonists. NC8-12 (100 nM), a selective sst ${ }_{2}$ agonist (cf. Tallent et al., 1996) had no significant effects on $\mathrm{K}^{+}$currents in RT neurons $(94 \pm 6 \%$ of control level; $n=7$; not significant). Octreotide (100 nM), an agonist for $\mathrm{sst}_{2}, \mathrm{sst}_{3}$, and $\mathrm{sst}_{5}$ receptors (Hoyer et al., 1995), activated GIRK currents in RT $(130 \pm 10 \%$ of control; $p<0.05$; with six of six neurons responding). Bim23052 (100 nM), a selective sst $_{5}$ agonist (cf. Tallent et al., 1996), also mimicked the effects of activation of $\mathrm{K}^{+}$currents by SST in RT neurons $(129 \pm 6 \%$ of control; $p<0.01$; with five of five neurons responding). These results suggest that the $\mathrm{sst}_{5}$ receptor subtype mediates the activation of $\mathrm{K}^{+}$currents in RT. Cyclo-SST (100 nM), a specific SST receptor antagonist, blocked the effects of the peptide on $\mathrm{K}^{+}$ currents (Fig. 2C2) ( $n=5$ of 6 cells), suggesting that these effects were mediated via activation of G-protein-coupled sst receptors, rather than nonspecific actions on the channels.

In VB neurons, the pharmacological profiles of SST-mediated responses were more complex. Although NC8-12 (100 nM) decreased resting $\mathrm{K}^{+}$conductance in 6 of 7 cells tested $(85 \pm 7 \%$ of control; $p<0.05$; data not shown), bim23052 (100 nм) and octreotide $(100 \mathrm{nM})$ consistently increased membrane conductance $(112 \pm 8 \%$ of control, $n=12$ of 14 cells, $p<0.01$, and $119 \pm 12 \%$ of control, $n=7$ of 8 cells, $p<0.01$, respectively). These results suggest that multiple SST receptors coexist in VB neurons, with $\mathrm{sst}_{2}$ receptors being negatively coupled and $\mathrm{sst}_{5}$ and possibly sst $_{3}$ positively coupled to GIRK channels.

\section{GIRK channels are the principal targets of SST receptor activation in $\mathrm{RT}$ neurons}

We characterized the types of $\mathrm{K}^{+}$channels modulated by SST by applying SST alone and in the presence of various ion channel blockers. In these experiments, a fast solution exchange method was used (cf. Sun et al., 2001a). We found that the effects of SST on $\mathrm{K}^{+}$currents occurred within 1 min (Figs. 2A2, 3A1, 8A1), consistent with direct G-protein-mediated responses (cf. Leubke and Dunlap, 1994; Sodickson and Bean, 1996; Viana and Hille, 1996) and similar to responses elicited by $\mathrm{NPY}_{1}$ receptormediated activation of GIRK channels in these neurons (Sun et al., 2001a). The activation of $\mathrm{K}^{+}$currents by SST was inhibited by a low concentration of $\mathrm{Ba}^{2+}(0.1 \mathrm{~mm})$ (Fig. $\left.3 A, B\right)$, which blocks GIRK currents in various CNS neurons (Sodickson and Bean, 1996; Sun et al., 2001a). Cs ${ }^{+}(500 \mu \mathrm{M})$, which also blocks GIRK and other $\mathrm{K}^{+}$channels, produced a similar block of SST effects (Fig. 3B2). Tertiapin-Q (20 nM), a very potent peptide inhibitor of recombinant GIRK ${ }_{1 / 4}$ channels (Jin and Lu, 1999), occluded 80\% of SST effects in RT (Fig. 3B2). To exclude the possibility of an effect of $\mathrm{Ba}^{2+}$ on constitutive GIRK channels, we applied $\mathrm{Ba}^{2+}$ $(0.1 \mathrm{~mm})$ before SST application. We found that $\mathrm{Ba}^{2+}$ alone
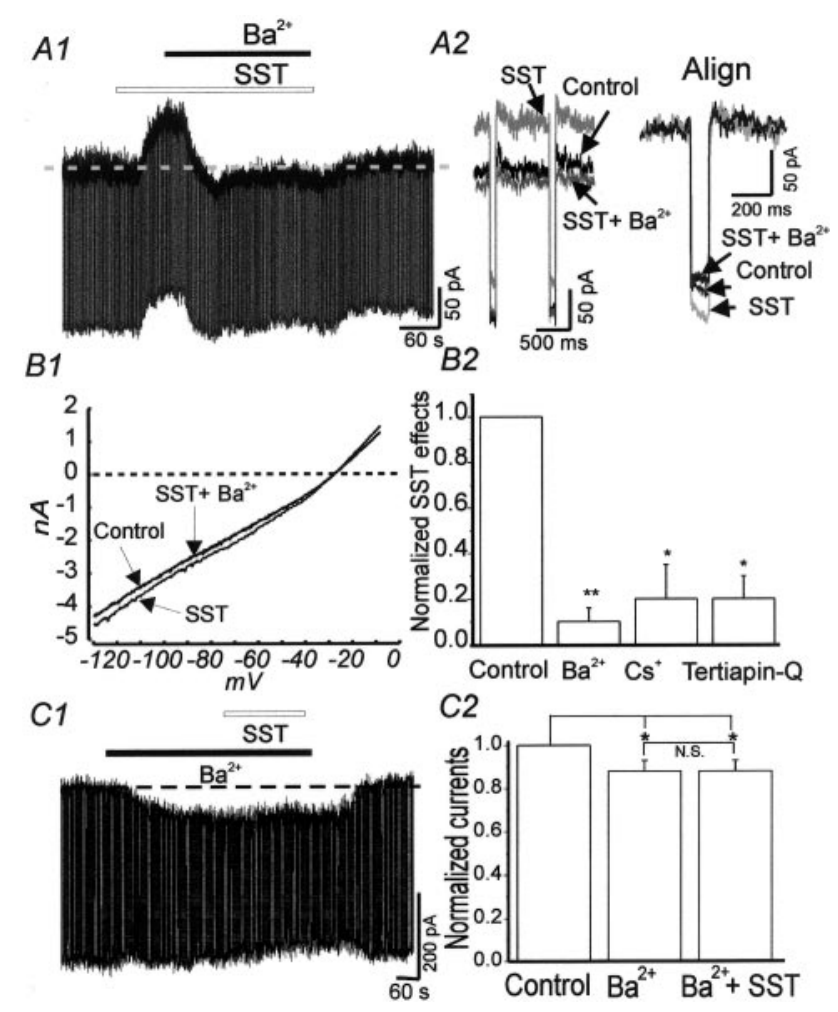

Figure 3. Effects of SST on $\mathrm{K}^{+}$currents were occluded by $0.1 \mathrm{~mm} \mathrm{Ba}^{2+}$, $0.1 \mathrm{mM} \mathrm{Cs}^{+}$, and $10 \mathrm{~nm}$ tertiapin-Q. A1, Continuous current record of experiment showing reversible effects of local perfusion with control solution, $200 \mathrm{~nm}$ SST, and SST $+0.1 \mathrm{~mm} \mathrm{Ba}^{2+}$. Dashed line, Baseline holding current; vertical lines, responses to $100 \mathrm{msec}$ voltage steps from -60 to $-75 \mathrm{mV}$, applied at $1 \mathrm{~Hz}$. A2, Left, Individual current responses in the four conditions of A1. SST elicited an outward shift of holding currents $(S S T)$, reversed by concurrent $\mathrm{Ba}^{2+}$ perfusion $\left(S S T+\mathrm{Ba}^{2+}\right)$. $A 2$, Right, Current responses aligned to baseline level demonstrate changes in conductance under different conditions. B1, Currents elicited by voltage ramps $(-130$ to $0 \mathrm{mV}, 1 \mathrm{sec})$ in $30 \mathrm{~mm}$ external $\mathrm{K}^{+}$in an RT neuron. The increased conductance produced by SST was occluded by 0.1 $\mathrm{mm} \mathrm{Ba}^{2+} . B 2$, Summary of effects of various ion channel blockers on SST-evoked currents in RT neurons. ${ }^{*} p<0.05,{ }^{*} p<<0.01$ vs SST alone ( $n=5-12$ for each treatment). C1, Continuous current record of experiment showing occlusion of SST effects by $0.1 \mathrm{mM} \mathrm{Ba}^{2+}$. Dashed line, Baseline holding current; vertical lines, responses to $100 \mathrm{msec}$ voltage steps from -60 to $-80 \mathrm{mV}$, applied at $1 \mathrm{~Hz}$. C2, Summary of $\mathrm{Ba}^{2+}$ preperfusion on SST-evoked currents in RT neurons. ${ }^{*} p<0.05(n=4)$.

reduced input conductance by $13 \pm 5 \%$, presumably because of blockade of constitutively active GIRK currents (Fig. 3C) $(n=5)$. SST had no effects in the presence $\mathrm{Ba}^{2+}$ (Fig. $3 C$ ). These results suggest that GIRK channels are the principal targets for SSTmediated modulation of excitability in RT neurons.

\section{Modulation of high-voltage-activated but not low- voltage-activated $\mathrm{Ca}^{2+}$ currents by SST}

Reliable whole-cell voltage-clamp recordings of voltage-gated $\mathrm{Ca}^{2+}$ currents were obtained in 24 of $58 \mathrm{RT}$ neurons (Figs. 4, 5, $6)$. Effective voltage and space clamp and the efficacy of voltage control in these neurons were verified using criteria described in a previous study (Sun et al., 2001a).

Whole-cell $\mathrm{Ca}^{2+}$ currents recorded from RT neurons demonstrate both T-type [low-voltage-activated (LVA)] and highvoltage-activated (HVA) components (cf. Coulter et al., 1989). T-type currents were elicited at test potentials positive to $-70 \mathrm{mV}$ and inactivated during a $100 \mathrm{msec}$ test pulse (Fig. 4A1,B1), 
A1
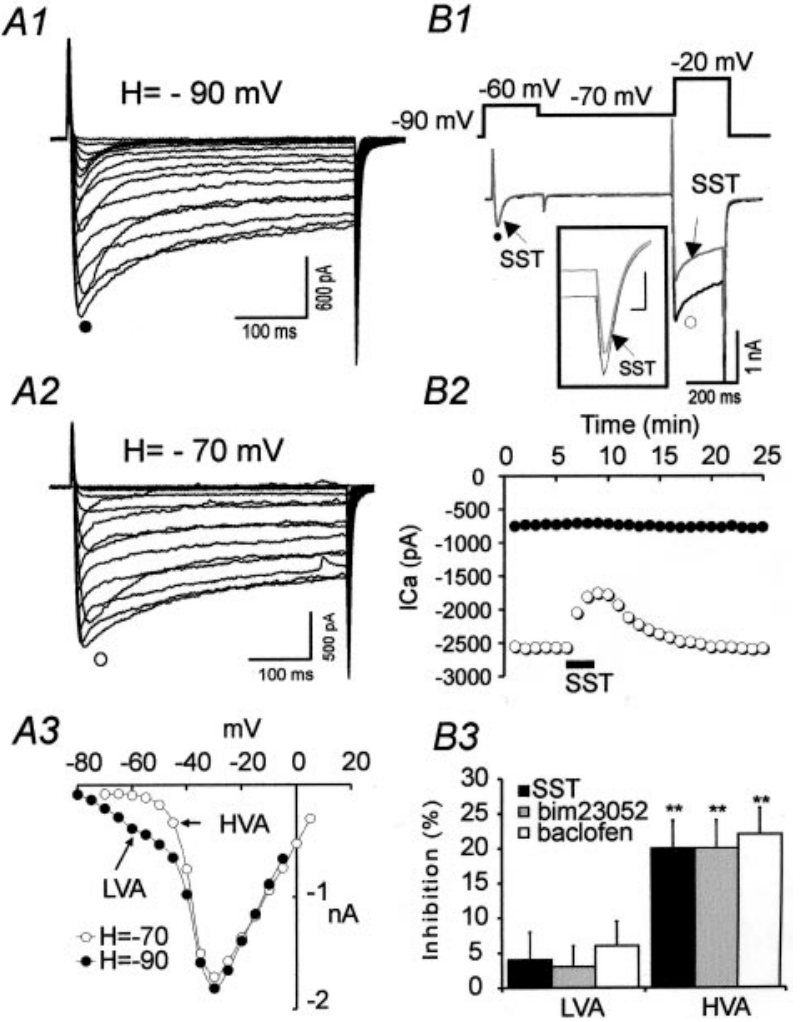

Figure 4. Effects of SST receptor agonists and baclofen on whole-cell $\mathrm{Ca}^{2+}$ currents. $A$, Whole-cell voltage-gated $\mathrm{Ca}^{2+}$ currents evoked in an $\mathrm{RT}$ neuron by voltage steps from a holding potential of $-90 \mathrm{mV}(A 1)$ or $-70 \mathrm{mV}(A 2)$ to test potentials between -80 and $+10 \mathrm{mV}$. $A 3, I-V$ curves measured from peak $\mathrm{Ca}^{2+}$ currents in $A 1$ and $A 2$ showing combined LVA and HVA current amplitudes $(\bullet)$ or HVA currents $(\bigcirc)$. B1, LVA $(\bullet)$ and HVA $(\bigcirc)$ currents that were elicited in an RT neuron by command steps of -60 and $-20 \mathrm{mV}$ from holding potentials of -90 and $-70 \mathrm{mV}$, respectively. HVA currents (and their associated tail currents) were specifically reduced by $500 \mathrm{~nm} \mathrm{SST} \mathrm{(arrow).} \mathrm{Inset,} \mathrm{HVA} \mathrm{Ca}^{2+}$ tail currents elicited in control (black trace) and SST (gray trace). Calibration: $2 \mathrm{msec}$, 400 pA. B2, Time-series measurements showing that the effects of SST were specific to HVA currents $(\bigcirc)$ and reversible in the same neuron. LVA currents (-) were unaffected. B3, Summary of effects of SST (100$500 \mathrm{nM}), \operatorname{Bim} 23052(200 \mathrm{nM})$, and baclofen $(5 \mu \mathrm{M})$ on LVA and HVA currents in RT neurons $(n=29)$. ${ }^{*} p<0.01$ vs control.

whereas HVA currents were evoked at potentials positive to -40 $\mathrm{mV}$ and showed less inactivation (Fig. $4 A$ ). Using a triple pulse protocol from an initial holding potential of $-90 \mathrm{mV}$, T-type and HVA currents were elicited, and the effects of SST on both were examined (Fig. 4B1). In 17 of 24 RT neurons, SST reversibly reduced $\mathrm{HVA} \mathrm{Ca}^{2+}$ currents but had no effects on T-type currents (Fig. 4B1,B2), results similar to those obtained with the $\mathrm{GABA}_{\mathrm{B}}$ receptor agonist baclofen (Fig. 4B3). The mean steadystate inhibition of HVA currents in responsive RT neurons was $20 \pm 5 \%$. These inhibitory effects of SST were mimicked by bim23052 (200 nм; $n=5)$ (Fig. 4B3) and octreotide (100 nм; $n=$ $8)$, but not by NC8-12 (50 nM, $n=5)$, suggesting that $\mathrm{sst}_{5}$ receptors mediated the effects of SST on $\mathrm{HVA} \mathrm{Ca}^{2+}$ currents.

\section{Effects of SST on HVA Ca ${ }^{2+}$ currents}

We examined the voltage-dependence of SST-mediated inhibition of HVA currents by using voltage ramps (500 msec; -70 to +20 $\mathrm{mV}$ ) to elicit these currents (Fig. 5A1). The relative inhibition elicited with either SST or baclofen varied with membrane potential and was a bell-shaped function of membrane voltage (Fig.

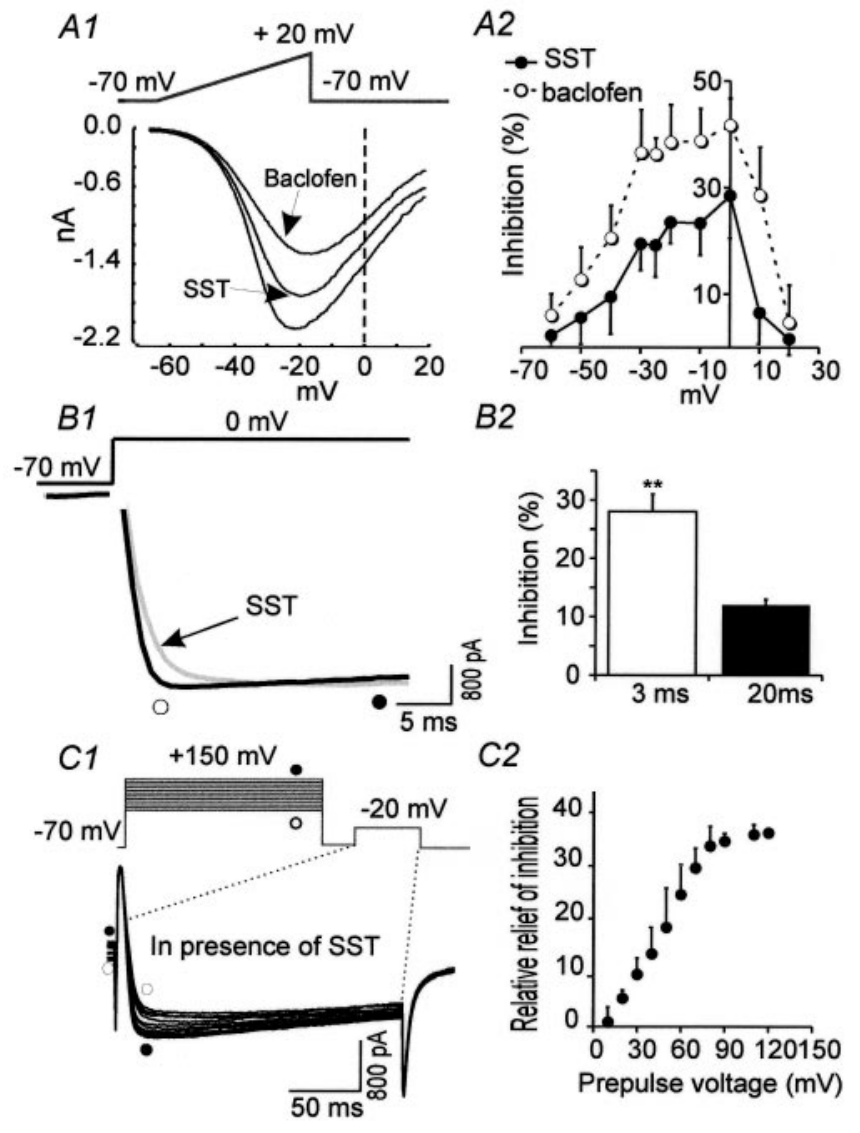

Figure 5. Voltage dependence of SST- and baclofen-mediated inhibition of HVA currents. $A 1$, Leak-subtracted HVA Ca ${ }^{2+}$ currents elicited by $500 \mathrm{msec}$ voltage ramps from -70 to $+20 \mathrm{mV}$ in control and in the presence of SST $(200 \mathrm{nM})$ or baclofen $(5 \mu \mathrm{M})$. A2, Plot of inhibition of HVA $\mathrm{Ca}^{2+}$ currents by SST and baclofen versus membrane potential $(n=6) . B 1$, Whole-cell, leak-subtracted $\mathrm{CA}^{2+}$ currents elicited by a test potential of $0 \mathrm{mV}$ from a holding potential of $-70 \mathrm{mV}$ in control (dark trace) and SST (light trace) showing slowed activation of $\mathrm{Ca}^{2+}$ currents by SST. Currents were normalized to approximately the same peak amplitude. Leak currents were obtained in the presence of $200 \mathrm{nM} \mathrm{Cd}^{2+}$. Vertical scale bar applies only to control currents. B2, Summary of inhibition of HVA Ca ${ }^{2+}$ currents by SST measured at 3 and $20 \mathrm{msec}$ from the onset of voltage steps $(n=6$; **p $p 0.01$ vs $20 \mathrm{msec})$. C1, Voltagedependent removal of inhibition of $\mathrm{HVA} \mathrm{Ca}^{2+}$ currents. Responses to $-20 \mathrm{mV}$ test pulses after $1 \mathrm{sec}$ conditioning steps to between +10 and 140 $\mathrm{mV}$ from an initial holding potential of $-70 \mathrm{mV}$ in the presence of SST. $C 2$, Plot of voltage dependence of the relief of inhibition for conditioning prepulses from +10 to $+130 \mathrm{mV}$ obtained from four neurons.

5A1,A2) $(n=7)$ (cf. Hille, 1994; Jones and Elmslie, 1997; Dolphin, 1998). Maximum inhibition occurred at membrane voltages near $0 \mathrm{mV}$. A small rightward shift in the $I-V$ curve was detected with either SST or baclofen (Fig. $5 A$ ). When steps to $0 \mathrm{mV}$ were applied, the time course of activation was clearly delayed by SST (Fig. 5B1, arrow) (cf. Bean, 1989; Sahara and Westbrook, 1993). The degree of inhibition was greater at the onset $(28 \pm 7 ; n=7)$ (Fig. 5B2) than at $20 \mathrm{msec}(13 \pm 2 \%)$ (Fig. 5B1,B2) (cf. Sahara and Westbrook, 1993; Leubke and Dunlap, 1994; Viana and Hille, 1996; Dolphin, 1998; Sun and Dale, 1998). Relief of SSTmediated inhibition of HVA currents was voltage dependent, as determined by analyzing the effect of conditioning prepulses. Half-maximal relief occurred at $+50 \mathrm{mV}$, with maximum effect at voltages $>100 \mathrm{mV}$ (Fig. 5C1,C2). In control solutions, these prepulses had very little effect on HVA calcium currents $(n=4$; 


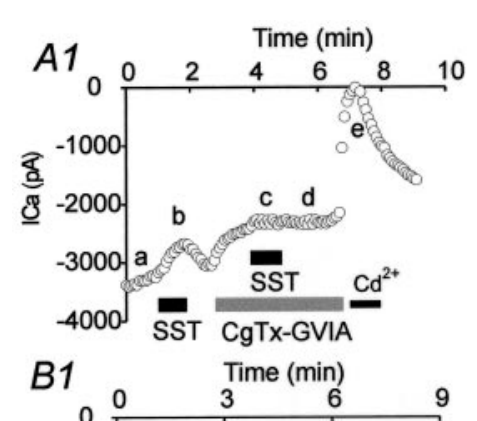

A2

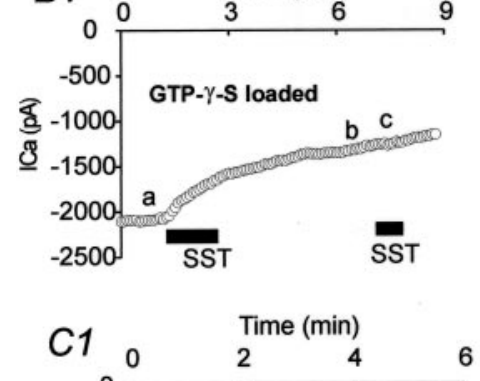

B2
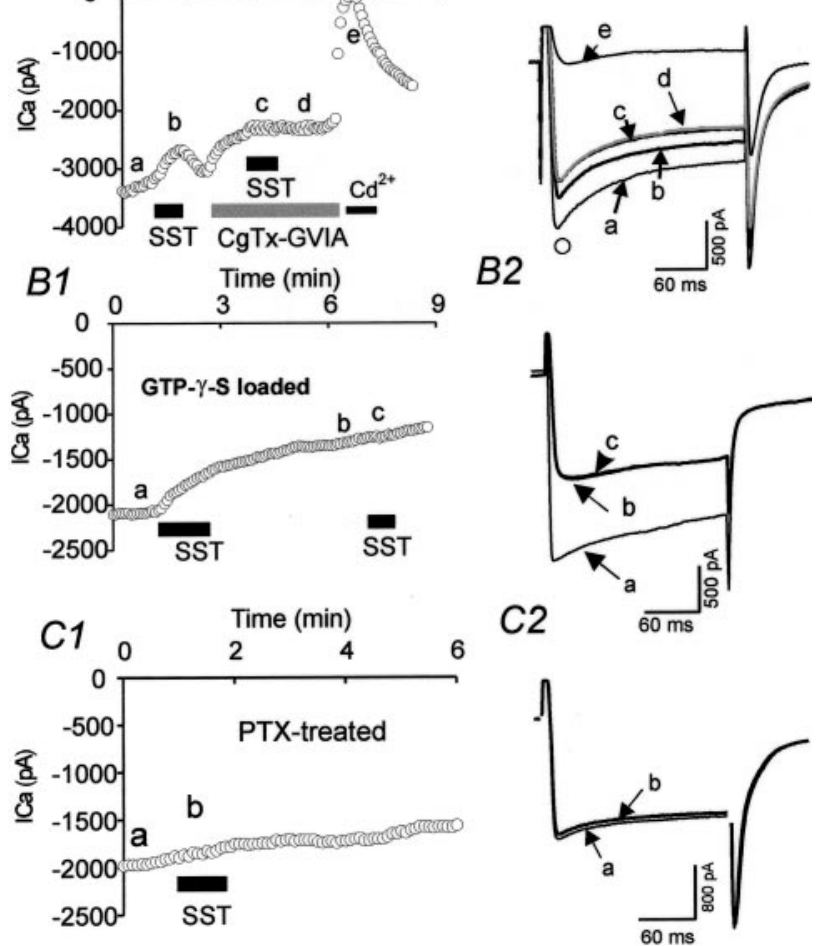

Figure 6. Inhibition of HVA currents by SST was mediated by pertussissensitive G-proteins activating via $\mathrm{N}$-type calcium channels. A1, Time series measurements showing the effects of $\omega$-CgTx-GVIA $(1 \mu \mathrm{M})$ and $\mathrm{Cd}^{2+}(200 \mu \mathrm{M})$ on SST inhibition of HVA currents in an RT neuron. $I_{\mathrm{Ca}}$ was measured at time indicated by $\bigcirc$ in $A 2$. The inhibition of HVA currents by SST ( $200 \mathrm{nM}$ ) was essentially blocked by $\omega$-conotoxin-GVIA $(1 \mu \mathrm{M})$. A2, HVA currents recorded at points corresponding to letters in $A 1$. B , Time series measurements (B1) and current traces (B2) showing effects of intracellular GTP- $\gamma-\mathrm{S}(100 \mu \mathrm{M})$ on SST-mediated inhibition of HVA currents in an RT neuron. Traces $a-c$ in $B 2$ were taken at times indicated in B1. C, Example of time series measurements $(C 1)$ and current traces $(C 2)$ showing effects of bath incubation with pertussis-toxin $(0.5 \mathrm{mg} / \mathrm{ml},>8 \mathrm{hr})$ on SST-mediated inhibition of HVA currents $\left(I_{\mathrm{Ca}}\right)$ in an RT neuron. Traces in $C 2$ were obtained at points $a$ and $b$ in $C 1$.

data not shown), indicating that the voltage-dependent relief of inhibition apparent in these nonleak-subtracted traces was not caused by changes in leak conductance. In summary, these results indicate that inhibition of $\mathrm{HVA} \mathrm{Ca}{ }^{2+}$ currents by SST is mediated by voltage-dependent mechanisms.

L-, N-, P/Q-, and R-type HVA Ca ${ }^{2+}$ channels are present in rat thalamic neurons (Huguenard and Prince, 1992; Kammermeier and Jones, 1997; Sun et al., 2001a). Because N- and P/Qtype calcium channels are most susceptible to voltage-dependent inhibition (for review, see Hille, 1994; Jones and Elmslie, 1997; Dolphin, 1998), we examined SST modulation of these channels. The effects of SST alone and in the presence of $\omega$-CgTx-GVIA (1 $\mu \mathrm{M})$ or $\omega$-agatoxin-TK (200 $\mathrm{nM})$ were studied to determine whether the blocking action of SST and each toxin was additive or occlusive. Results showed that $\omega$-CgTx-GVIA virtually eliminated SST-sensitive currents $(5 \pm 3 \%$ inhibition after $\omega$-CgTxGVIA treatment, $p<0.05$, vs $24 \pm 3 \%$ effects in control; $n=5$ ) (Fig. $6 A$ ), whereas $\omega$-agatoxin had no significant effects on SSTmediated inhibition of HVA currents $(22 \pm 4 \%$ inhibition after $\omega$-agatoxin treatment vs $20 \pm 5 \%$ inhibition in controls; data not shown; $n=5$ ). These results suggests that N-type HVA channels are the predominant target for inhibition by SST.

\section{G-proteins are involved in modulation of $\mathrm{K}^{+}$and $\mathrm{Ca}^{2+}$ currents}

The effects of SST on both HVA Ca ${ }^{2+}$ currents and $\mathrm{K}^{+}$currents were blocked by intracellular loading of GDP- $\beta$-S (100 $\mu \mathrm{M} ; n=6$; inhibition $8 \pm 3$ and $4 \pm 1 \%$, respectively, not significant vs controls; data not shown). By contrast, the inhibition of HVA $\mathrm{Ca}^{2+}$ currents by SST was irreversibly enhanced in cells loaded with GTP- $\gamma-\mathrm{S}(100 \mu \mathrm{M} ; 40 \pm 5 \%$ inhibition; $n=4)$ (Fig. 6B). These data suggest that G-proteins are involved in SST-mediated responses. In slices treated with pertussis toxin $(0.5 \mathrm{mg} / \mathrm{ml} ; 8-11$ hr of preincubation), both T-type and HVA currents were indistinguishable from control currents (data not shown). However, the effects of SST on both HVA Ca ${ }^{2+}$ currents $(n=5 ; 6 \pm 2 \%$; not significant vs controls) (Fig. $6 C)$ and $\mathrm{K}^{+}$currents $(5 \pm 3 \%$; $n=6$; data not shown) were virtually abolished. This suggests that pertussis toxin-sensitive G-proteins $\left(\mathrm{G}_{\mathrm{i} / \mathrm{o}}\right)$ (cf. Hille, 1994) were involved.

\section{Effects of SST on excitatory neurotransmission in RT neurons}

Isolated EPSCs were evoked in RT neurons by electrical stimuli delivered to the internal capsule (IC) in the presence of the $\mathrm{GABA}_{\mathrm{A}}$ receptor antagonist bicuculline $(10-20 \mu \mathrm{M})$. Typical monosynaptic EPSCs had a reversal potential $\sim 0 \mathrm{mV}$, an early rapidly decaying component at $-70 \mathrm{mV}$, and both rapidly and more slowly decaying components at positive potentials (Fig. 7A1, inset). The early, fast component exhibited a near linear currentvoltage relationship (Fig. 7A1, inset, $\bigcirc$ ), consistent with a prominent AMPA/kainate receptor component, whereas the late phase was outwardly rectifying (Fig $7 A 1$, inset, $\triangle$ ), consistent with a prominent NMDA receptor contribution. EPSCs evoked by a train of stimuli (40-80 msec interstimulus interval) showed shortterm plasticity, which was manifest most commonly as short-term depression (five of eight cells) (Fig. 7A1,A2), occasionally as facilitation (two of eight; data not shown) or early facilitation followed by late depression (one of eight). Addition of SST reversibly reduced the amplitude of evoked EPSCs in RT neurons (Fig. $7 A 2, A 3 ; A 4$ for summary) without any change in the kinetics of individual EPSCs (Fig. 7A2, inset). This suggests the involvement of presynaptic mechanisms. Furthermore, the inhibition by SST varied during each train, with the largest inhibition occurring at first response within the train $(37 \pm 8 \% ; n=8)$ (Fig. $7 A 1 ; A 4$ for summary) and progressively less inhibition toward the end of the train $(25 \pm 5 \%$ inhibition at the fourth response in the train; $n=8 ; p<0.001$; vs $37 \pm 8 \%$ inhibition at the first response; tested by one-way ANOVA analysis with Tukey-Kramer multiple comparison test). When the relative inhibition within a train response was normalized, short-term relief of inhibition occurred, with $30 \%$ relief occurring at fourth stimulus compared with the first (Fig. 7A4) ( $p<0.001)$, suggesting that voltage-dependent modulation mediated by SST occurred at this synapse (Parker and Dunlap, 1998; cf. Brody and Yue, 1999). The SST-mediated differential effect on the EPSCs elicited at the start and end of the train suggests changes in the short-term plasticity. Indeed, in all eight neurons examined, the paired-pulse ratio increased during SST application regardless of what forms of short-term plasticity occurred in control conditions (Fig. 7A2).

We examined the effects of SST on mEPSCs recorded in the presence of $1 \mu \mathrm{M}$ TTX and found that SST reversibly reduced the frequency (Fig. 7B1,B2) $(33 \pm 8 \%$ decrease; $p<0.05 ; n=6)$ but not the amplitude of mEPSCs in RT neurons (Fig. 7B3). These 
A1

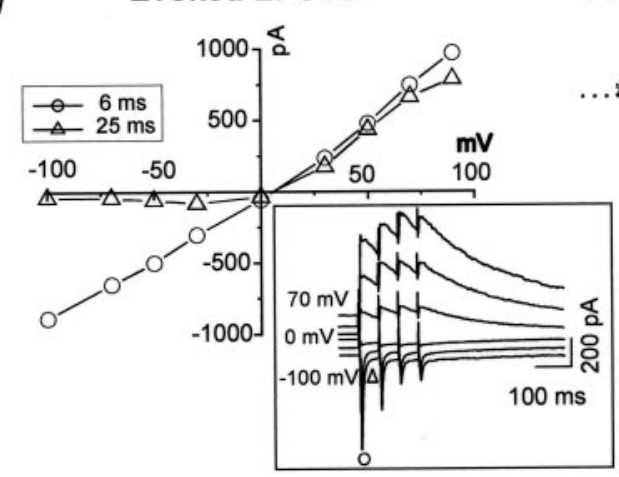

A2

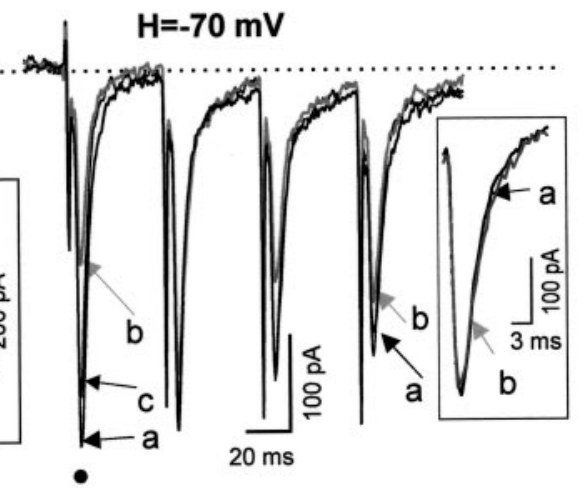

A3

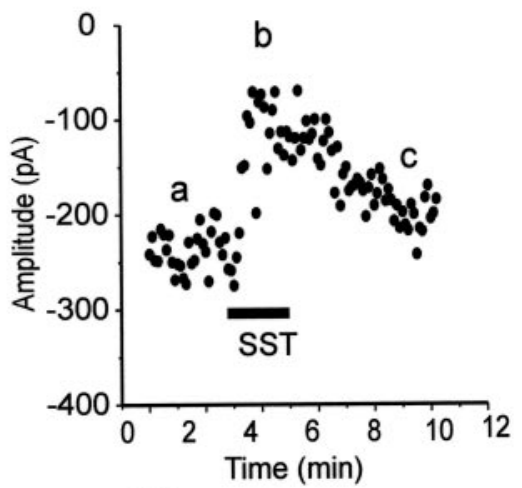

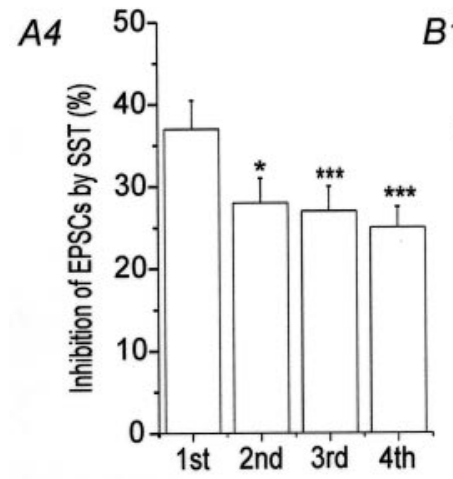

$B 1$
B2

B3

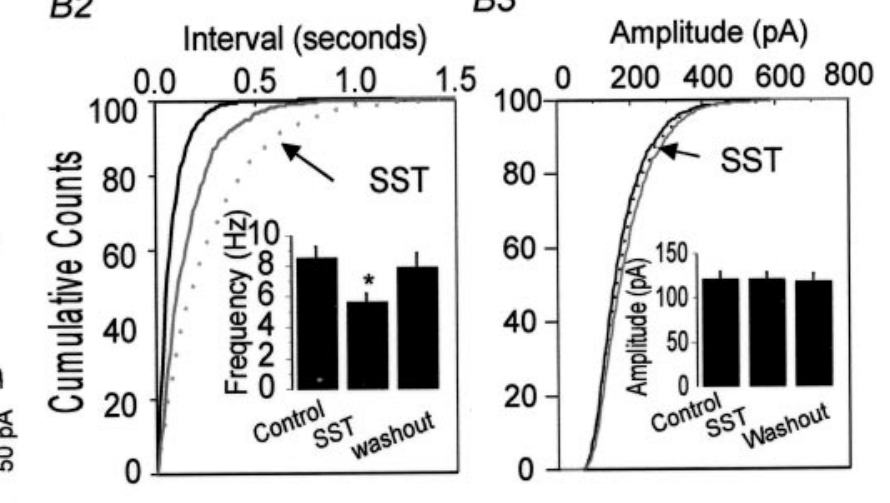

Figure 7. Effects of SST on eEPSCs and mEPSCs in RT neurons. A1, Current-voltage relations of initial EPSC of each train in inset. Current amplitude measured at $6 \mathrm{msec}(\bigcirc)$ and $25 \mathrm{msec}(\triangle)$ latency, as shown in $-100 \mathrm{mV}$ trace of inset. Inset, Averaged EPSCs evoked by a train of stimuli $(20 \mathrm{~Hz})$

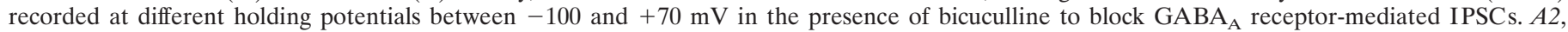
Representative EPSCs evoked by a $20 \mathrm{~Hz}$ stimulus train in control (a, black traces), SST (200 nM) (b, gray traces), and washout (c, darker traces) recorded at a holding potential of $-70 \mathrm{mV}$ in an RT neuron. The inset shows superimposed, scaled responses of the first EPSCs in the train in control and SST conditions. A3, Time course of SST-mediated effects on the amplitude of the first EPSCs from the same experiment as that depicted in A2. A4, Summary of effects of SST on the amplitude of various EPSCs within the train responses $\left({ }^{* * *} p<0.001,{ }^{*} p<0.05\right.$ vs first EPSC; one-way ANOVA analysis with Tukey-Kramer multiple comparison test $n=8) . B 1, \mathrm{mEPSC}$ recorded at $V_{\mathrm{hold}}=-80 \mathrm{mV}$ in an RT neuron in the presence of bicuculline $(20 \mu \mathrm{M})$ and TTX $(1 \mu \mathrm{M})$. Traces are control (top), $100 \mathrm{nM}$ SST (middle), and 3 min after washout (bottom). B2, B3, Cumulative probability plots of mEPSC inter-events intervals (B2) and amplitudes (B3) from 3 min epochs before, during, and 3 min after the application of SST in cell of B1. Inset, Mean frequency $(B 2)$ but not amplitude $(B 3)$ of mEPSCs in RT $(n=6)$ was significantly reduced by SST $\left({ }^{*} p<0.05\right.$ vs control and washout).

results suggest that SST acts presynaptically to reduce glutamate release.

\section{SST preferentially inhibits burst discharges evoked by near-threshold inputs}

During both normal and epileptiform oscillations, RT neurons fire bursts of action potentials and provide a major GABAergic input to relay neurons (von Krosigk et al., 1993; Huguenard and Prince, 1994). SST has previously been shown to directly inhibit release of GABA from RT terminals onto thalamic relay neurons (Leresche et al., 2000). Effects such as those described above that alter either presynaptic excitatory neurotransmitter release or postsynaptic membrane excitability could affect burst generation in RT neurons and thus influence network oscillations. We next tested the possibility that SST would inhibit RT neuron discharge evoked by excitatory synaptic inputs onto these neurons.

In experiments with normal artificial CSF (see Materials and Methods), extracellular stimulus trains $(20-50 \mathrm{~Hz}$; three to five stimuli) applied to the internal capsule (Fig. 8A2) elicited EPSPs in RT neurons (Fig. 8A1). The EPSPs included those originating from both corticothalamic and thalamocortical inputs onto RT neurons (cf. Turner and Salt, 1998; Blumenfeld and McCormick,
2000). In the majority of cells tested ( $n=12 / 15)$, we found that EPSPs elicited by trains of stimuli $(25 \mathrm{~Hz})$ showed robust facilitation characterized by supralinear summation (Fig. 8A1). Increases in stimulus intensity resulted in increased EPSP amplitude and $\mathrm{Na}^{+}$-dependent action potentials (Fig. 8A1). The probability of spike firing, the number of spikes per stimulus, and the integrated area (millivolts $\times$ milliseconds) of the depolarization all increased with stimulus intensity (Fig. 8A1) (cf. Steriade, 1999). SST preferentially reduced the number of action potentials evoked by small to moderate amplitude EPSCs (Fig. 8B1,B2). This effect can also be seen in the plot of Figure $8 B 3$, which shows an inverse relationship between control EPSP magnitude (area) and SST-dependent spike inhibition (Fig. 8B3) $(r=-0.71 ; p<$ $0.001 ; n=84$ responses). These results suggest that during evoked network oscillations, SST may preferentially regulate discharges of RT neurons evoked by threshold EPSP inputs and have weaker effect on bursts generated by strong inputs.

The effects of SST on synaptic responses were usually accompanied by a small membrane hyperpolarization (Fig. 8B1). Because SST had both presynaptic effects on glutamate release (Fig. 7) and postsynaptic effects on $\mathrm{K}^{+}$currents (Fig. 2) [and mem- 

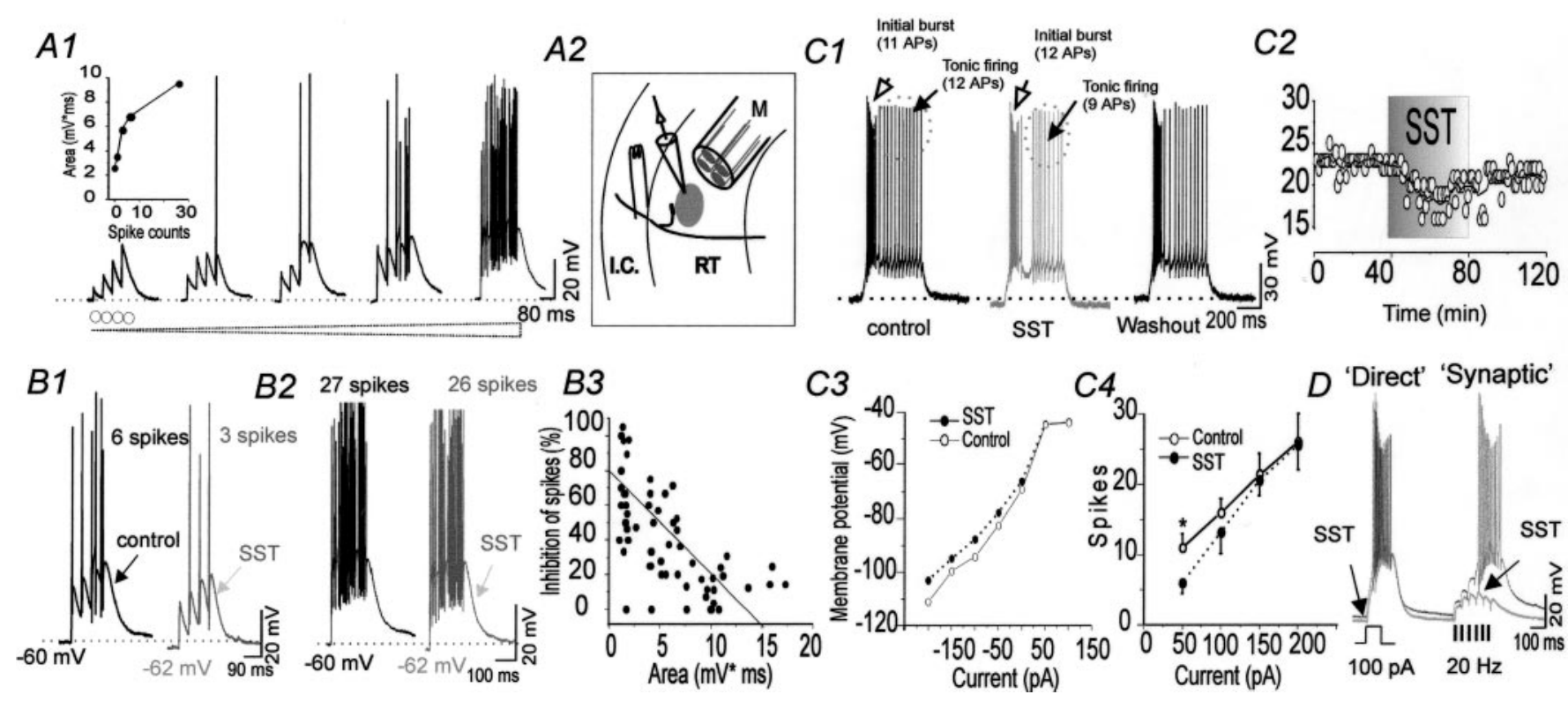

$D$ 'Direct' 'Synaptic'

Figure 8. SST decreased the probability of evoked burst discharge by near-threshold stimulation in RT neurons. A1, Whole-cell current-clamp recordings of EPSPs and action potentials elicited in an RT neuron by a train of four stimuli delivered to the internal capsule. Increasing the stimulation intensity resulted in larger EPSPs and a progressive increase in the number of action potentials within each burst. Traces progressing from left to right are responses evoked by 4, 6, 8, 10, and $12 \mu \mathrm{A}$ stimulus trains (each pulse $40 \mu \mathrm{sec}$ ), respectively. Inset, Compound EPSP area as a function of the number of spikes within each burst, demonstrating the nonlinear amplification of spike output with larger EPSP amplitudes. Both values increased as a function of stimulus strength, but spike counts increased dramatically with the strongest stimuli. $A 2$, A schematic depicting the thalamic circuit with recording sites. $M$, Multibarrel local perfusion pipette; $I C$, internal capsule; $R T$, thalamic reticular nucleus. $B 1, B 2$, Burst discharge elicited by threshold $(10 \mu \mathrm{A}, B 1)$ and more intense (30 $\mu \mathrm{A}, B 2)$ stimuli in control (darker traces) and SST (lighter traces) in the same neuron as $A$. B3, Scatter plot of percentage depression of spike number versus control depolarization area in seven RT neurons. The solid line is a linear regression with $r=-0.71, p<0.0001(n=84)$. $C$, Current-clamp recordings of burst and tonic firing in an RT neuron elicited by direct current injection ( 1 sec duration, $+80 \mathrm{pA})$ in control condition (left), during $100 \mathrm{~nm}$ SST application (middle, gray trace), and after SST washout (right). Note that SST reduced the repetitive spiking (arrow) but had very little effect on resting membrane potentials and initial low-threshold bursts (open arrowhead). Dotted line represents resting membrane potential level. C2, Time course of SST-mediated effects on the total spikes per stimulus from the same experiment as that depicted in $A 2$. C3, Voltage-current relation for the neuron of $C 1$. C4, Current-spike relation in control $(\bigcirc)$ and during SST application $(\bullet)$ for six RT neurons. * $p<0.05$ vs controls. $D$, Burst discharges in an RT neuron elicited by direct current injection $(100 \mathrm{msec}$ duration, $100 \mathrm{pA}$; responses on the left $)$ or a train of four stimuli $(20 \mathrm{~Hz})$ delivered to the internal capsule (responses on the right). SST (100 nM; light traces) did not affect the bursts evoked by direct current injection (left) but abolished the synaptically evoked bursts (right). All responses in $A, B$, and $D$ were obtained in the presence of $20 \mu \mathrm{M}$ BMI.

brane potential hyperpolarization (Fig. $8 B, C$ )], we next examined how the two effects contributed to the SST-dependent suppression of synaptically evoked bursts. We elicited complex spike (burst + tonic) discharges in RT neurons with a range of direct depolarizing currents and found that SST preferentially inhibited tonic firing, especially that elicited by near-threshold currents (Fig. 8C1,C2,C4). SST increased the membrane conductance (Fig. 8C3), an effect consistent with activation of $\mathrm{K}^{+}$ channels. In contrast to the effect of SST on EPSC-triggered bursts (Fig. 8B1-3), which occurred over a wide range of EPSPs, the effects on direct-current-triggered bursts were only manifest with the smallest stimulus intensity $(50 \mathrm{pA} ; n=4)$ (Fig. 8C4). When comparable burst discharges were evoked in the same neuron by applying direct current (100 pA) (Fig. $8 D)$ and synaptic stimuli, the latter were more powerfully inhibited. Note in particular how the train of EPSPs failed to summate to trigger a regenerative burst after SST application in Figure $8 D$. Taken together, these results suggest that the bursts elicited by weak to moderate strength synaptic inputs are more prone to suppression by SST.

Addition of the $\mathrm{GABA}_{\mathrm{A}}$ receptor antagonist BMI can alter thalamic network oscillations such that RT excitability is increased and epileptiform activity prevails (Fig. 11) (von Krosigk et al., 1993; Huguenard and Prince, 1994; for review, see Huguenard and Prince, 1997). We next examined the effects of SST on
RT cell bursts under these conditions. To mimic the repetitive activation of excitatory synapses during epileptiform $3 \mathrm{~Hz}$ oscillations, trains of stimuli were applied to the internal capsule to elicit burst discharges. Brief trains of $20-25 \mathrm{~Hz}$ stimuli were delivered at $3 \mathrm{~Hz}$ with a total two to four trains within a train group. Train groups were applied once per minute (Fig. 9A1). Repetitive bursts in RT cells were elicited during the stimuli and were blocked by bath perfusion of ionotropic glutamate receptor antagonists CNQX and APV (data not shown; $n=4$ ). In eight neurons tested, SST produced a $6 \pm 1 \mathrm{mV}$ hyperpolarization and concomitantly inhibited the discharges elicited by the late (second through fourth) trains within a train group $(75 \pm 10 \%$ reduction in spike number; $p<0.05 ; n=5$ ) but not the first train within the cycle $(10 \pm 8 \% ; p>0.1 ; n=5)$ (Fig. 9A2). The inhibitory effects of SST on firing could not be fully accounted for by SST-induced membrane hyperpolarization, because direct depolarizing current injection was unable to reverse the effects of SST on spike generation (60 $\pm 11 \%$ inhibition; $n=5)$ (Fig. 9, compare $A 2 c$, $A 2 b$ ). In cells in which network oscillatory responses were recorded, SST had very little effect on the powerful bursts activated by extracellular stimuli (Fig. $9 B 1, B 2, \bullet)$ but exerted strong inhibitory effects on the bursts activated by recurrent network EPSPs (Fig. 9B1,B2, arrows). As a result, both the duration and spike count of oscillations were reduced by SST. 
Figure 9. Effects of SST on RT neuronal responses under conditions of bicuculline methiodide $\left(\begin{array}{ll}10 & \mu \mathrm{M}\end{array}\right)$ application. $A 1$, Whole-cell current-clamp recording of burst discharges in an RT neuron elicited by stimuli to the internal capsule. The stimulus train parameters are described in Results. Dotted horizontal line indicates level of resting membrane potential in control $(-70 \mathrm{mV})$. Filled bar indicates the time when SST (500 nM) was applied, and open bar indicates the time when depolarizing direct current was applied to restore membrane potential to control levels. $A 2$, Expanded time base showing stimulus train-evoked discharges in Control, SST, and $S S T+D . C$. injection. Traces in $A 2$ were obtained at points $a-c$ in $A 1$. Note that SST significantly reduced the number of spikes elicited in the second train but had little effect on the first train. B1, Intracellular recordings of evoked $(\mathbf{0})$ and spontaneous (arrow) bursts and EPSPs from an RT neuron in control condition (bottom), during $100 \mathrm{~nm}$ SST application (indicated by shaded bar), and after washout (top). B2, Superimposed recordings from the same experiment as that depicted in B1. Note that SST (gray trace) had no effect on the initial evoked discharges $(\bullet)$ and small effects on both resting membrane potential $(-2 \mathrm{mV})$ and the initial spontaneous bursts ( first arrow), but it virtually abolished the late spontaneous bursts (second and third arrow) and also reduced the amplitude of late subthreshold EPSPs (third arrow).
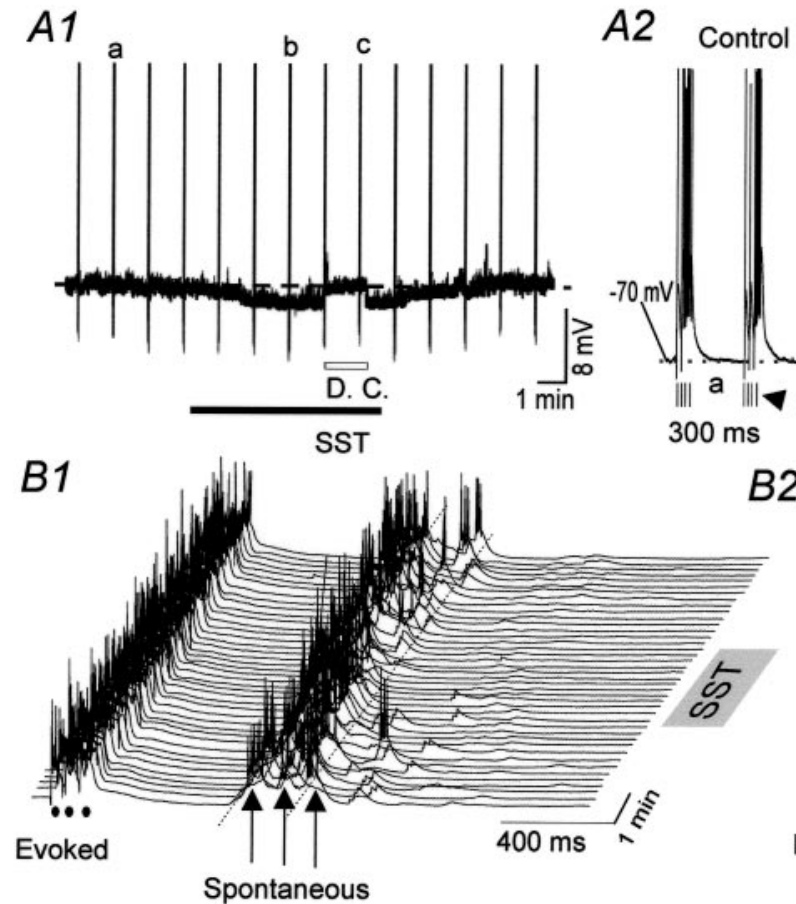

A2

Control SST SST+ D.C.

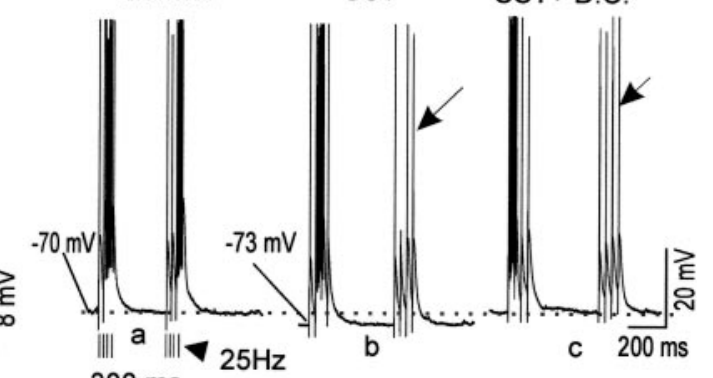

$B 2$

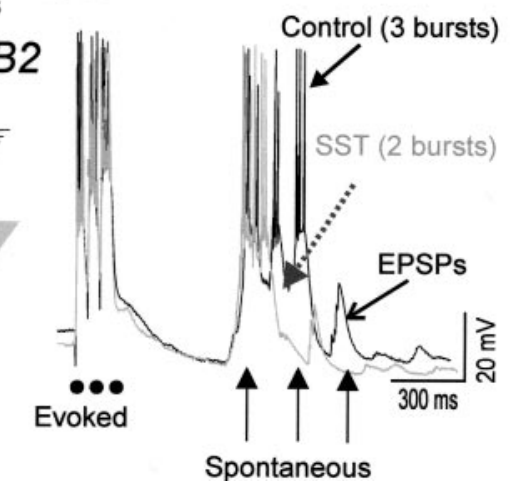

\section{Effects of SST on intrathalamic oscillations in vitro}

We studied the effects of SST on two variants of intrathalamic oscillatory rhythms (Jacobsen et al., 2001): (1) spindle-like oscillations, with a dominant frequency of $6-8 \mathrm{~Hz}$, that occur in normal physiological saline, and (2) epileptiform, hypersynchronous activity with a dominant frequency of $3 \mathrm{~Hz}$ that results from addition of BMI.

In normal physiological solutions, extracellular activities evoked in VB and RT by stimulating the IC are composed of repetitive burst discharges over a period of $1-5 \mathrm{sec}$, similar to activity occurring during sleep spindles (Fig. 10A1-4). Fast Fourier Transform (FFT) analysis indicated that these oscillatory activities had no predominant peak, although scattered local peaks ranged from 1 to $7 \mathrm{~Hz}$. During baseline recordings before application of SST, both the number of spikes in each episode and the duration of the network oscillations remained relatively constant over a period of 10s of minutes in these slices (Fig. 10A5). However, when SST (100 nM) was applied, there was an abrupt and reversible reduction in total spikes evoked per oscillation to $45 \pm 9 \%$ of control (Fig. 10A3,B) $(p<0.05)$. The reduction in neuronal activity was mediated predominantly by a shortening of episode duration (50 $\pm 9 \%$ reduction) (Fig. 10A3) $(n=5 ; p<$ $0.05)$, because SST had little effect on the activity within the first few cycles (Fig. 10A3). SST also reduced the total FFT power throughout the entire frequency range measured (data not shown). In slices in which oscillations were simultaneously recorded from both RT and VB nuclei, the total "spindle-like" activity in both nuclei was reduced to a similar extent (Fig. 10A5), indicating that SST inhibited spindle-like extracellular activities by suppression of reciprocal network activities.

We next tested the effects of SST in slices bathed with $2 \mu \mathrm{M}$ BMI to block $\mathrm{GABA}_{\mathrm{A}}$-mediated IPSPs and enhance RT cell firing. Under these conditions, the duration, synchrony, and strength of intrathalamic oscillations were greatly enhanced (von
Krosigk, 1993; Huguenard and Prince, 1994; Cox et al., 1997; Jacobsen et al., 2001). This epileptiform oscillatory activity occurred in episodes lasting up to $10 \mathrm{sec}$ (Fig. $11 \mathrm{~A}$, Table 1), with predominant frequency peaks near $3 \mathrm{~Hz}$ (Fig. 11D, Table 1). These highly synchronized epileptiform activities depend on the intrinsic properties of thalamic neurons and $\mathrm{GABA}_{\mathrm{B}}$ receptormediated slow IPSPs (Crunelli and Leresche, 1991; Steriade et al., 1993; Huguenard and Prince, 1994; Ulrich and Huguenard, 1996). In these slices, addition of SST (100 nм) reduced the episode duration (65\% of control) (Fig. 11A,B, Table 1), the time constant of oscillation decay ( $75 \%$ of control) (Table 1), and the total spike count (65\% of control) (Fig. 11A, Table 1). Therefore, the predominant effect of SST on synchronized intrathalamic oscillations is inhibitory. Interestingly, SST paradoxically increased the oscillatory index (see Materials and Methods) by $25 \%$ (Fig. 11C, Table 1), indicating an increase in synchrony. FFT analysis revealed that during baseline activities, the oscillation had multiple frequency components, with the primary peak power frequency in the $3.0-3.3 \mathrm{~Hz}$ range (Table 1 ) and secondary peaks between 2.5 and $4 \mathrm{~Hz}$ (Fig. 11D). During SST application, the main peak frequency was slowed slightly to $\sim 2.9 \mathrm{~Hz}$ (Table 1), and secondary peaks were mostly attenuated (Fig. 11D). This reduced variability could account for the enhanced synchrony produced by SST. In addition, it could also be caused by reduction of spontaneous neuronal activities occurring between burst cycles (data not shown). In summary, our results suggest that exogenous activation of SST receptors results in novel changes that include earlier termination of burst episodes and a paradoxical alteration of the pattern of paroxysmal oscillations evoked in thalamic slices.

\section{DISCUSSION}

\section{Modulation of GIRK channels}

SST modulates several classes of $\mathrm{K}^{+}$currents. For example, this peptide increases a linear "leak" current in rat CA1 neurons 


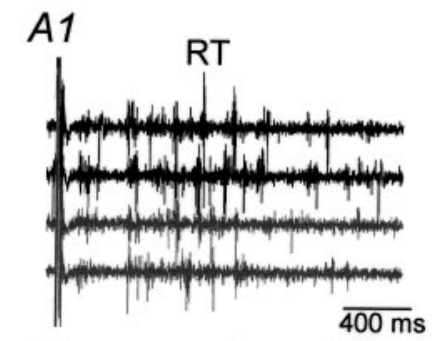

A3
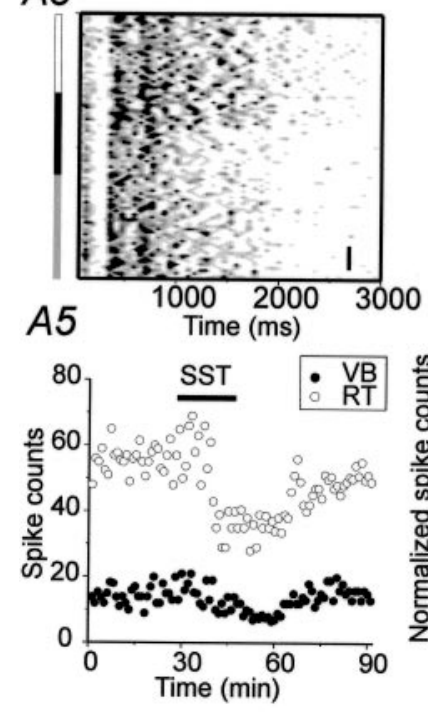

A2

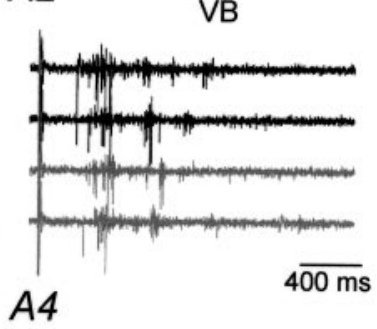

A4
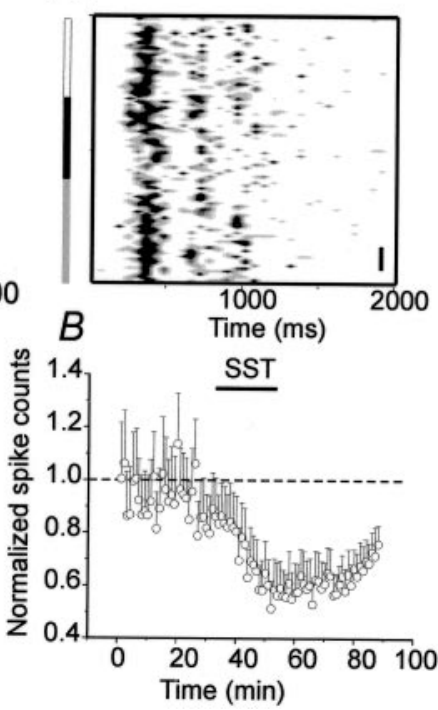

Figure 10. Modulation of thalamic spindle-like oscillations by SST in vitro. $A 1, A 2$, Extracellular multiunit recordings of oscillatory activity in $\mathrm{RT}(A 1)$ and VB $(A 2)$ in response to single extracellular stimuli in control solution (top 2 darker traces; 15 min after the start of recording) and during $100 \mathrm{~nm}$ SST application (bottom 2 gray traces; 15 min after the start of SST application). $A 3, A 4$, Contour plot of rate meter output (cf. Jacobsen et al., 2001) depicting the time course of the same experiment in $\mathrm{RT}(A 3)$ and VB (A4) from recordings as in $A 1$ and $A 2$. The $x$-axis represents time within each evoked oscillation, whereas the $y$-axis represents the time course throughout the experiment. Time calibration for $y$-axis: $2 \mathrm{~min}$. Bar to left shows time of perfusion with control solution (clear), SST (black), and wash (gray). The $z$-axis represents the spike intensity during a single evoked oscillation; darker grays correspond to higher frequencies. Note decrease in activity and shortening of episode duration during SST application. A5, Effects of SST on total spikes per event in the same experiment as in $A 1-A 4$. B, Summary of effects of SST on spike counts in RT in five experiments in different slices.

(Schweitzer et al., 1998), activates or blocks an inward rectifier $\mathrm{K}^{+}$current (Inoue et al., 1988; Dichter et al., 1990; Tallent et al., 1996), increases or decreases delayed rectifier currents in cortical neurons (Wang et al., 1989) and in rod and cone photoreceptors (Akopian et al., 2000), and increases $\mathrm{Ca}^{2+}$-activated $\mathrm{K}^{+}$currents in chick parasympathetic neurons (White et al., 1997). By contrast, in rat RT neurons the effects of SST (via activation of $\mathrm{sst}_{5}$ receptors) on $\mathrm{K}^{+}$currents were primarily mediated by GIRK channels, because they were blocked by GIRK inhibitors, including $\mathrm{Ba}^{2+}, \mathrm{Cs}^{+}$and Tertiapin-Q. When expressed in Xenopus oocytes, rat $\mathrm{sst}_{2-5}$ receptors were activated by octreotide and coupled to coexpressed GIRK $_{1}$ channels, whereas sst $_{1}$ receptors

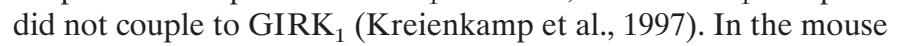
pancreatic cell line MIN-6, five SST receptor types, sst $_{1-5}$, were detected; however, only $\mathrm{sst}_{5}$ receptor subtypes were found to be coupled to GIRK channels (Smith et al., 2001). Our results in RT neurons are thus consistent with these actions of SST in non-

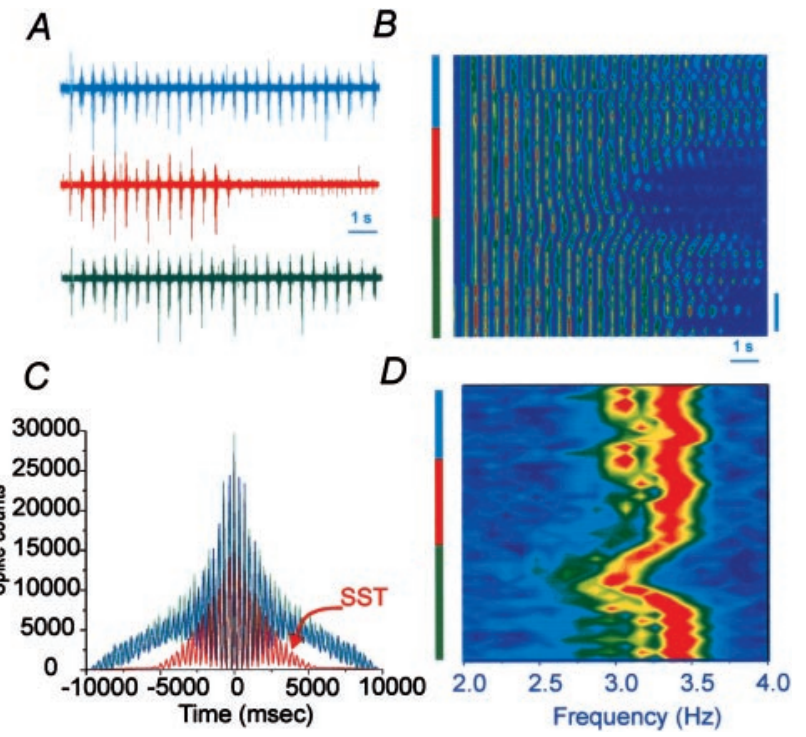

Figure 11. Modulation of thalamic epileptiform oscillations by SST in vitro. A, Extracellular multiunit recordings of bicuculline-enhanced oscillatory activity in response to single extracellular stimulus in control solution (top, blue; 10 min after start of recording), during 100 nм SST application (middle, red; 10 min after onset of SST application), and after SST washout (bottom, green; $15 \mathrm{~min}$ after SST washout). The evoked rhythmic discharges lasted $>10 \mathrm{sec}$ in control but only $\sim 6 \mathrm{sec}$ in SST. $B$, Contour plot reflecting rate-meter output of the same experiment. The $z$-axis represents the spike intensity during a single evoked oscillation. $x$ and $y$-axes are as in Figure 10, whereas in this figure the $z$-axis is color coded: warmer color levels (red, yellows) correspond to higher firing frequencies. The oscillatory phasic activity evoked by internal capsule stimulation continues throughout the sample period $(\sim 27$ cycles over 10 $\mathrm{sec}$ ) in control and washout conditions (blue and green bars, left). In the presence of $100 \mathrm{~nm} \mathrm{SST} \mathrm{(red} \mathrm{bar,} \mathrm{middle} \mathrm{left),} \mathrm{the} \mathrm{spike} \mathrm{discharge} \mathrm{ceased}$ after $\sim 6-7 \mathrm{sec}$. Time calibration is $5 \mathrm{~min}$ for $y$-axis. $C$, Autocorrelograms of the same experiment illustrating the overall decrease in activity (decreased amplitude of the central peak) but increased synchrony (higher peak-to-valley ratio) in SST (red, blue, and green lines represent control, SST, and washout). $D$, Three-dimensional color map of surface plots of FFT analysis of the same experiment, which demonstrate the frequency changes. The ordinate represents the time course throughout the experiment (top blue bar, pre-drug; middle red bar, SST; bottom blue bar, SST washout), whereas the abscissa represents frequency and the $z$-axis represents Fourier power. Time calibration for $y$-axis in $D$ as in $B$. Warmer color levels (red, yellows) correspond to higher Fourier power. In control conditions, rhythmic activity had a main peak frequency of $3.5 \mathrm{~Hz}$ and a second peak at $3.2 \mathrm{~Hz}$. Shortly after SST application, the amplitude of main peak was reduced, its frequency shifted to $2.9 \mathrm{~Hz}$, whereas the second peak was virtually abolished. This shift of frequency recovered toward baseline level in the washout. In this experiment, the extracellular perfusate contained $2 \mu \mathrm{M}$ bicuculline and $1.2 \mathrm{mM} \mathrm{Mg}^{2+}$.

neuronal preparations. The pharmacological characterization of receptor subtypes in the present experiments was based on agonist effects studied in populations of thalamic neurons. Octreotide (an sst ${ }_{2}$, sst $_{3}$, sst $_{5}$ agonist) and the specific sst ${ }_{5}$ receptor agonist BIM23052 mimicked SST effects. It is unlikely that $\mathrm{SST}_{3}$ receptors are involved, because NC8-12, which has a high affinity (0.09 nM) for $\mathrm{SST}_{3}$ receptors (cf. Tallent et al., 1996) and a low affinity for $\mathrm{SST}_{5}$ receptors $(>1000 \mathrm{nM})$, did not mimic the effects of SST on $\mathrm{K}^{+}$currents. Therefore, $\mathrm{sst}_{5}$ receptors are most likely involved.

Four currently identified subtypes of G-protein-coupled inward rectifier $\mathrm{K}^{+}$channels (GIRK1-4) are expressed in different regions of the CNS (for review, see Yamada et al., 1998). These channels are abundantly expressed in thalamic neurons (Ponce et 


\begin{tabular}{|c|c|c|c|c|}
\hline Parameters & Control & SST & Wash & $p$ value \\
\hline Oscillatory index (OI, \%) & $46 \pm 13(n=5)$ & $54 \pm 13(n=5)^{* *}$ & $42 \pm 12(n=5)$ & $<0.001$ \\
\hline$\tau$ of oscillation (msec) & $992 \pm 295(n=5)$ & $762 \pm 220(n=5)^{*}$ & $951 \pm 388(n=5)$ & $<0.05$ \\
\hline Episode duration (msec) & $3430 \pm 1772(n=5)$ & $2260 \pm 1090(n=5)$ & $3280 \pm 1782(n=5)$ & $<0.1$ \\
\hline Total spikes & $466 \pm 145(n=5)$ & $308 \pm 77(n=5)^{*}$ & $452 \pm 140(n=5)$ & $<0.05$ \\
\hline Frequency $(\mathrm{Hz})$ & $3.10 \pm 0.06(n=5)$ & $2.90 \pm 0.02(n=5)^{*}$ & $3.00 \pm 0.04(n=5)$ & $<0.05$ \\
\hline
\end{tabular}

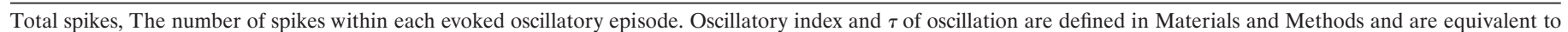
parameters used in earlier studies (cf. Cox et al., 1997; Huntsman et al., 1999).

al.,1996; Drake et al., 1997) where they may underlie the $\mathrm{GABA}_{\mathrm{B}}$ receptor-mediated "slow IPSCs" associated with 3-5 Hz thalamic oscillations (Crunelli and Leresche, 1991; Huguenard and Prince, 1994; Ulrich and Huguenard, 1996). Recent evidence suggests that these channels may also contribute to the modulation and fine-tuning of reticular and relay cell excitability by other neurotransmitters, such as neuropeptide Y (Sun et al., 2001a,b). GIRK channels can increase their activity by several orders of magnitude during G-protein stimulation (Nemec et al., 1999) and therefore may contribute to dynamic changes in resting membrane conductance (Sun et al., 2001a). In hippocampal neurons, GIRK channels are colocalized with various metabotropic neurotransmitter receptors, and their major physiological role is to increase $\mathrm{K}^{+}$conductance at the postsynaptic membrane and alter neuronal excitability (Lüscher et al., 1997).

Recently, a background leak current that depends on TASK-1 channels in motor neurons (Millar et al., 2000; Talley et al., 2000) was found to be a target for neurotransmitter modulation. TASK-1 channels are also expressed in thalamus (cf. Talley et al., 2000) and could potentially underlie many previously reported modulatory effects of neurotransmitters. However, TASK channel activation is unlikely to be responsible for the SST-mediated $\mathrm{K}^{+}$ currents in thalamus for the following reasons: (1) the $\mathrm{IC}_{50}$ of $\mathrm{Ba}^{2+}$ sensitivity for TASK channels is $\sim 10$ times higher than the $\mathrm{Ba}^{2+}$ concentration used in this study; (2) TASK-1 channels do not show inward rectification (Millar et al., 2000; Talley et al., 2000 ); and (3) $<40 \%$ of TASK-1 channels would be active under our experimental conditions $(\mathrm{pH}=7.4)$ (cf. Millar et al., 2000; Talley et al., 2000).

\section{Modulation of HVA channels and presynaptic inhibition of neurotransmitter release}

Based on biophysical characterizations, there are two known forms of modulation of voltage-gated $\mathrm{Ca}^{2+}$ channels: voltagedependent inhibition and voltage-independent inhibition (cf. Bean, 1989; Bernheim et al., 1991; Sahara and Westbrook, 1993; Shapiro and Hille, 1993; Luebke and Dunlap, 1994; DiverséPierluissi et al., 1995; Sun and Dale, 1997, 1998) (for review, see Dolphin, 1998). Although voltage-dependent inhibition is mediated by direct interaction between $\mathrm{Ca}^{2+}$ channels and G-protein $\beta \gamma$ subunits (for review, see Dolphin, 1998), the mechanisms responsible for voltage-independent inhibition are not clear. Sst $_{5}$ receptor-mediated effects on HVA channels in thalamic neurons are predominantly voltage dependent (Fig. 5) and coupled to pertussis toxin-sensitive G-proteins. These properties are similar to those mediated by $s_{2}$ receptors in rat amygdaloid neurons (Viana and Hille, 1996).

Because HVA channels, particularly $\mathrm{N}$ and $\mathrm{P} / \mathrm{Q}$ types, support synaptic transmission in CNS neurons (Leubke et al., 1993; Takahashi and Momiyama, 1993; Turner et al., 1993), their mod- ulation by neurotransmitters can contribute to the presynaptic inhibition of transmitter release (Toth et al., 1993; Yawo and Chuhma, 1993). If modulation of N-type calcium channels occurs at intrathalamic synaptic terminals, it could contribute to inhibition of GABA release from RT neurons (cf. Leresche et al., 2000) or glutamate release onto RT neurons and thalamocortical neurons, depending on the localization of SST receptors. Because thalamic neurons are capable of firing high-frequency bursts with maximum action potential amplitude greater than $+20 \mathrm{mV}$, the voltage-dependent inhibition of $\mathrm{Ca}^{2+}$ channels could undergo dynamic relief (Park and Dunlap, 1998). Recent evidence suggests that such relief of neurotransmitter receptor-mediated inhibition of $\mathrm{HVA} \mathrm{Ca}{ }^{2+}$ channels contributes to short-term synaptic plasticity in hippocampal neurons (Brody and Yue, 2000). Indeed we found that the effects of SST on evoked EPSCs are relieved during stimulus trains (Fig. 7).

\section{Cellular mechanisms underlying SST-mediated modulation of network oscillations}

The most robust effect of SST on network oscillations was a dramatic shortening of evoked oscillation duration (to $\sim 40 \%$ of control) (Table 1), resulting in early termination of epileptiform and spindle-like oscillations. It has been suggested that termination of intrathalamic oscillations may be attributable to the gradual activation of an intrinsic conductance in relay neurons, specifically a hyperpolarization-activated cation-selective ion channel $\left(I_{\mathrm{H}}\right)$ (Bal and McCormick, 1996). Neurotransmitters released from brainstem neurons, such as serotonin and norepinephrine, can contribute to termination of spindle oscillations through enhancement of $I_{\mathrm{H}}$ (Lee and McCormick, 1996). Our results demonstrate that SST modulates GIRK potassium channels and N-type calcium channels in RT neurons but has no effect on $I_{\mathrm{H}}$ channels in relay neurons (our unpublished observations). The major functional consequence of SST receptor activation for RT cells seems to be a reduction in responsiveness to excitatory inputs from corticothalamic and thalamocortical neurons. In particular, the probability of evoking a burst response, especially with near-threshold stimuli that evoke small EPSPs, is decreased dramatically (40-100\% depression) (Fig. 8B3). By contrast, robust burst discharges were still evoked in RT cells under conditions of strong excitatory synaptic input (Fig. 8B2,B3). This is presumably because SST produced only a moderate hyperpolarization (approximately $-4 \mathrm{mV})$, a slight $(\sim 15 \%)$ increase of resting membrane conductance, and a modest $(\sim 30 \%)$ reduction of the amplitude of EPSPs onto RT neurons. All of these effects could thus presumably be overcome by powerful excitatory synaptic input. Postsynaptic mechanisms alone cannot account for SST-mediated inhibition of synaptic burst generation, because bursts elicited by direct currents in the same cell were not affected, whereas those generated by synaptic inputs of comparable strength were 
strongly suppressed (Fig. 8D). Furthermore, the effect of SST on bursts is not caused by membrane hyperpolarization alone, because returning membrane potential to pre-SST levels with DC current injection did not restore the burst generating capacity of the neuron (Fig. 9A1,A2). Under the more physiological circumstances of recurrent network activity, the ability of late "spontaneous" EPSCs to elicit bursts was selectively reduced by SST (Fig. $9 B 1, B 2)$. These results suggest that the combined presynaptic and postsynaptic effects lead to more powerful suppression of network activity than would be expected from either mechanism alone.

Rebound burst discharges in VB neurons evoked by trains of IC stimuli were either slightly enhanced or not affected by SST (our unpublished observations), although the peptide produced a $\sim 20 \%$ inhibition of the evoked complex IPSPs $\left(\mathrm{GABA}_{\mathrm{B}}+\mathrm{GABA}_{\mathrm{A}}\right)$ (Leresche et al., 2001). Thus, the regulation of RT cell discharge by SST appears to be primarily responsible for the SST-mediated termination of synchronized network oscillations. Interestingly, an earlier study revealed that low concentrations of CCK can increase the duration of the rhythmic activity without altering the baseline discharge rate (Cox et al., 1997). The mechanisms underlying CCK-mediated prolongation of synchronized oscillations are not clear; however, CCK depolarized reticular neurons and increased the probability of obtaining burst discharges during synaptic stimulation.

The paradoxical effects of SST on the pattern of the intrathalamic oscillations were unexpected. Although SST decreased spike count and the duration of bicuculline-enhanced, highly synchronized oscillations by $30 \%$, and suppressed the less synchronized spindle-like oscillations by $45 \%$, it increased the oscillatory index (i.e., it enhanced synchrony) of bicuculline-enhanced responses by $25 \%$. This latter result might be explained by the preferential inhibitory effect of SST on baseline tonic spontaneous discharges and discharges triggered by near-threshold synaptic inputs. For example, our results obtained from GIRK and $\mathrm{Ca}^{2+}$ current experiments suggest that $\mathrm{sst}_{5}$ receptor activation could be responsible for reduction of the probability of synaptically evoked RT discharge. The modest $(\sim 30 \%)$ inhibitory actions of SST on evoked EPSCs in RT neurons may have preferential effects on desynchronized synaptic inputs that would then be less able to summate and evoke action potentials. On the other hand, highly synchronized oscillatory activities would be less affected, until they begin to wane as excitatory synaptic drive diminishes at the termination of a network event. This explanation is supported by the results of intracellular recordings (Fig. $9 B$ ) showing that bursts elicited by early and strong synaptic inputs are not affected by SST, whereas bursts evoked by late and weak EPSPs are diminished (Fig. 9A2,B2), with a resultant enhanced synchronization.

In summary, SST decreases thalamic network excitability through multiple actions at different sites, including activation of postsynaptic $\mathrm{K}^{+}$channels of RT neurons, inhibition of glutamate release onto RT neurons, and consequent anti-oscillatory effects. These actions of SST, along with the frequency-dependent release and long-term effects characteristic of peptides, would make SST an ideal endogenous anti-epileptic neurotransmitter in thalamocortical epilepsies.

\section{REFERENCES}

Akopian A, Johnson J, Gabriel R, Brecha N, Witkovsky P (2000) Somatostatin modulates voltage-gated $\mathrm{K}^{+}$and $\mathrm{Ca}^{2+}$ currents in rod and cone photoreceptors of the salamander retina. J Neurosci 20:929-936.
Bal T, McCormick DA (1996) What stops synchronized thalamocortical oscillations? Neuron 17:297-308.

Bean BP (1989) Neurotransmitter inhibition of calcium currents by changes in channel voltage dependence. Nature 340:153-156.

Bendotti C, Hohmann C, Forloni G, Reeves R, Coyle JT, Oster-Granite ML (1990) Developmental expression of somatostatin in mouse brain. II. In situ hybridization. Brain Res Dev Brain Res 53:26-39.

Bernheim L, Beech DJ, Hille B (1991) A diffusible second messenger mediates one of the pathways coupling receptors to calcium channels in rat sympathetic neurons. Neuron 6:859-867.

Blumenfeld H, McCormick DA (2000) Corticothalamic inputs control the pattern of activity generated in thalamocortical networks. J Neurosci 20:5153-5162.

Brody DL, Yue DT (2000) Relief of G-protein inhibition of calcium channels and short-term synaptic facilitation in cultured hippocampal neurons. J Neurosci 20:889-898.

Buckmaster PS, Jongen-Relo AL (1999) Highly specific neuron loss preserves lateral inhibitory circuits in the dentate gyrus of kainate-induced epileptic rats. J Neurosci 19:9519-9529.

Burgunder JM, Young III WS (1992) Expression of cholecystokinin and somatostatin genes in the human thalamus. J Comp Neurol 324:14-22.

Chow A, Erisir A, Farb C, Nadal MS, Ozaita A, Lau D, Welker E, Rudy $\mathrm{B}(1999) \mathrm{K}^{+}$channel expression distinguishes subpopulations of parvalbumin- and somatostatin-containing neocortical interneurons. J Neurosci 19:9332-9345.

Cox CL, Huguenard JR, Prince DA (1995) Cholecystokinin depolarizes rat thalamic reticular neurons by suppressing a $\mathrm{K}^{+}$conductance. J Neurophysiol 74:990-1000.

Cox CL, Huguenard JR, Prince DA (1997) Peptidergic modulation of intrathalamic circuit activity in vitro: actions of cholecystokinin. J Neurosci 17:70-82.

Coulter DA, Huguenard JR, Prince DA (1989) Calcium currents in rat thalamocortical relay neurones: kinetic properties of the transient, low-threshold current. J Physiol (Lond) 414:587-604.

Cropper EC, Price D, Tenenbaum R, Kupfermann I, Weiss KR (1990) Release of peptide cotransmitters from a cholinergic motor neuron under physiological conditions. Proc Natl Acad Sci USA 87:933-937.

Crunelli V, Leresche N (1991) A role for GABAB receptors in excitation and inhibition of thalamocortical cells. Trends Neurosci 14:16-21.

Dichter MA, Wang HL, Reisine T (1990) Electrophysiological effects of somatostatin-14 and somatostatin-28 on mammalian central nervous system neurons. Metabolism 39:86-90.

Diversé-Pierluissi M, Goldsmith PK, Dunlap K (1995) Transmittermediated inhibition of N-type calcium channels in sensory neurons involves multiple GTP-binding proteins and subunits. Neuron 14:191-200.

Dolphin AC (1998) Mechanisms of modulation of voltage-dependent calcium channels by G-proteins. J Physiol (Lond) 506:3-11.

Dournaud P, Gu YZ, Schonbrunn A, Mazella J, Tannenbaum GS, Beaudet A (1996) Localization of the somatostatin receptor SST2A in rat brain using a specific anti-peptide antibody. J Neurosci 16:4468-4478.

Drake CT, Bausch SB, Milner TA, Chavkin C (1997) GIRK immuno- $^{-}$ reactivity is present predominantly in dendrites, dendritic spines, and somata in the $\mathrm{CA}_{1}$ region of the hippocampus. Proc Natl Acad Sci USA 94:1007-1012.

Edwards FA, Konnerth A, Sakmann B, Takahashi T (1989) A thin slice preparation for patch clamp recordings from neurones of the mammalian central nervous system. Pflügers Arch 14:600-612.

Epelbaum J (1986) Somatostatin in the central nervous system: physiology and pathological modifications. Prog Neurobiol 27:63-100.

Graybiel AM, Elde RP (1983) Somatostatin-like immunoreactivity characterizes neurons of the nucleus reticularis thalami in the cat, monkey. J Neurosci 3:1308-1321.

Hille B (1994) Modulation of ion-channel function by G-protein-coupled receptors. Trends Neurosci 17:531-536.

Hoyer D, Bell GI, Berelowitz M, Epelbaum J, Feniuk W, Humphrey PP, O'Carroll AM, Patel YC, Schonbrunn A, Taylor JE, Reisine T (1995) Classification and nomenclature of somatostatin receptors. Trends Pharmacol Sci 16:86-88.

Huguenard JR, Prince DA (1992) A novel T-type current underlies prolonged $\mathrm{Ca}^{2+}$-dependent burst firing in GABAergic neurons of rat thalamic reticular nucleus. J Neurosci 12:3804-3817.

Huguenard JR, Prince DA (1994) Intrathalamic rhythmicity studied in vitro: nominal T-current modulation causes robust anti-oscillatory effects. J Neurosci 14:5485-5502.

Huguenard JR, Prince DA (1997) Basic mechanisms of epileptic discharge in the thalamus. In: Thalamus (II), pp 295-330. New York: Elsevier.

Huntsman MM, Porcello DM, Homanics GE, DeLorey TM, Huguenard JR (1999) Reciprocal inhibitory connections and network synchrony in the mammalian thalamus. Science 283:541-543.

Inoue M, Nakajima S, Nakajima Y (1988) Somatostatin induces an inward rectification in rat locus coeruleus neurones through a pertussis toxin-sensitive mechanism. J Physiol (Lond) 407:177-198.

Jacobsen RB, Ulrich D, Huguenard JR (2001) Gaba(B) and NMDA 
receptors contribute to spindle-like oscillations in rat thalamus in vitro. J Neurophysiol 86:1365-1375.

Jan LY, Jan YN (1982) Peptidergic transmission in sympathetic ganglia of the frog. J Physiol (Lond) 327:219-246.

Jin W, Lu Z (1999) Synthesis of a stable form of tertiapin: a high-affinity inhibitor for inward-rectifier K ${ }^{+}$channels. Biochemistry 38:14286-14293.

Jones SW, Elmslie KS (1997) Transmitter modulation of neuronal calcium channels. J Membr Biol 155:1-10.

Kammermeier PJ, Jones SW (1997) High-voltage-activated calcium currents in neurons acutely isolated from the ventrobasal nucleus of the rat thalamus. J Neurophysiol 77:465-475.

Kawaguchi Y, Kubota Y (1996) Physiological and morphological identification of somatostatin- or vasoactive intestinal polypeptide-containing cells among GABAergic cell subtypes in rat frontal cortex. J Neurosci 16:2701-2715.

Kreienkamp HJ, Honk HH, Ritcher D (1997) Coupling of rat somatostatin receptor subtypes to a G-protein gated inwardly rectifying potassium channel (GIRK1). FEBS Lett 419:92-94.

Kubota Y, Kawaguchi Y (2000) Dependence of GABAergic synaptic areas on the interneuron type and target size. J Neurosci 20:375-386.

Lee KH, McCormick DA (1996) Abolition of spindle oscillations by serotonin and norepinephrine in the ferret lateral geniculate and perigeniculate nuclei in vitro. Neuron 17:309-321.

Leresche N, Asprodini E, Emri Z, Cope DW, Crunelli V (2000) Somatostatin inhibits GABAergic transmission in the sensory thalamus via pre-synaptic receptors. Neuroscience 98:513-522.

Llinas R, Ribary U (1993) Coherent 40-Hz oscillation characterizes dream state in humans. Proc Natl Acad Sci USA 90:2078-2081.

Luebke JI, Dunlap K (1994) Sensory neuron N-type calcium currents are inhibited by both voltage-dependent and independent mechanisms. Pflügers Arch 428:499-507.

Lüscher C, Jan LY, Stoffel M, Malenka RC, Nicoll RA (1997) G protein-coupled inwardly rectifying $\mathrm{K}^{+}$channels (GIRKs) mediate postsynaptic but not presynaptic transmitter actions in hippocampal neurons. Neuron 19:687-695.

Matsuoka N, Kaneko S, Satoh M (1991) A facilitatory role of endogenous somatostatin in long-term potentiation of the mossy fiber-CA3 system in guinea-pig hippocampus. Neurosci Lett 129:177-180.

McCormick DA, Prince DA (1987) Actions of acetylcholine in the guinea-pig and cat medial and lateral geniculate nuclei in vitro. J Physiol (Lond) 392:147-165.

McCormick DA, Prince DA (1988) Noradrenergic modulation of firing pattern in guinea pig, cat thalamic neurons in vitro. J Neurophysiol 59:978-996.

Millar JA, Barratt L, Southan AP, Page KM, Fyffe RE, Robertson B, Mathie A (2000) A functional role for the two-pore domain potassium channel TASK-1 in cerebellar granule neurons. Proc Natl Acad Sci USA 97:3614-3618.

Nemec J, Wickman K, Clapham DE (1999) G $\beta \gamma$ binding increases the open time of IKACh: kinetic evidence for multiple $\mathrm{G} \beta \gamma$ binding sites. Biophys J 76:246-252.

Park D, Dunlap K (1998) Dynamic regulation of calcium influx by G-proteins, action potential waveform, and neuronal firing frequency. J Neurosci 18:6757-6766.

Ponce A, Bueno E, Kentros C, Vega-Saenz de Miera E, Chow A, Hillman D, Chen S, Zhu L, Wu MB, Wu X, Rudy B, Thornhill WB (1996) G-protein-gated inward rectifier $\mathrm{K}^{+}$channel proteins $\left(\mathrm{GIRK}_{1}\right)$ are present in the soma and dendrites as well as in nerve terminals of specific neurons in the brain. J Neurosci 16:1990-2001.

Prince DA, Farrell D (1969) "Centrencephalic" spike-wave discharges following parenteral penicillin injection in the cat. Neurology 19:309-310.

Sahara Y, Westbrook GL (1993) Modulation of calcium currents by a metabotropic glutamate receptor involves fast and slow kinetic components in cultured hippocampal neurons. J Neurosci 13:3041-3050.

Schweitzer P, Madamba SG, Siggins GR (1998) Somatostatin increases a voltage-insensitive $\mathrm{K}^{+}$conductance in rat CA1 hippocampal neurons. J Neurophysiol 79:1230-1238.

Shapiro MS, Hille B (1993) Substance P, somatostatin inhibit calcium channels in rat sympathetic neurons via different $G$ protein pathways. Neuron 10:11-20.

Sloviter RS (1987) Decreased hippocampal inhibition and a selective loss of interneurons in experimental epilepsy. Science 235:73-76.

Sodickson DL, Bean BP (1996) GABA $_{\mathrm{B}}$ receptor-activated inwardly rectifying potassium current in dissociated hippocampal CA3 neurons. J Neurosci 16:6374-6385.
Steriade M (1999) Coherent oscillations and short-term plasticity in corticothalamic networks. Trends Neurosci 22:337-345.

Steriade M, Llinas RR (1988) The functional states of the thalamus and the associated neuronal interplay. Physiol Rev 68:649-742.

Steriade M, McCormick DA, Sejnowski TJ (1993) Thalamocortical oscillations in the sleeping and aroused brain. Science 262:679-685.

Stroh T, Kreienkamp HJ, Beaudet A (1999) Immunohistochemical distribution of the somatostatin receptor subtype 5 in the adult rat brain: predominant expression in the basal forebrain. $J$ Comp Neurol 12:69-82.

Smith PA, Sellers LA, Humphrey PP (2001) Somatostatin activates two types of inwardly rectifying $\mathrm{K}^{+}$channels in MIN-6 cells. J Physiol (Lond) 532:127-142.

Sun QQ, Dale N (1997) Serotonergic inhibition of the T-type and high voltage-activated $\mathrm{Ca}^{2+}$ currents in the primary sensory neurons of Xenopus larvae. J Neurosci 17:6839-6849.

Sun QQ, Dale N (1998) Differential inhibition of $\mathrm{N}$ and $\mathrm{P} / \mathrm{Q} \mathrm{Ca}^{2+}$ currents by $5-\mathrm{HT}_{1 \mathrm{~A}}$ and $5-\mathrm{HT}_{1 \mathrm{D}}$ receptors in spinal neurons of Xenopus larvae. J Physiol (Lond) 510:103-120.

Sun QQ, Huguenard JR, Prince DA (2001a) Neuropeptide Y receptors differentially modulate GIRK channels and $\mathrm{HVA} \mathrm{Ca}^{2+}$ channels in rat thalamic neurons. J Physiol (Lond) 531:67-79.

Sun QQ, Akk G, Huguenard JR, Prince DA (2001b) Differential regulation of GABA release and neuronal excitability mediated by neuropeptide $\mathrm{Y} 1$ and $\mathrm{Y} 2$ receptors in rat thalamic neurons. J Physiol (Lond) 531:81-94.

Takahashi T, Momiyama A (1993) Different types of calcium channels mediate central synaptic transmission. Nature 366:156-158.

Tallent M, Liapakis G, O'Carroll AM, Lolait SJ, Dichter M, Reisine T (1996) Somatostatin receptor subtypes SSTR2 and SSTR5 couple negatively to an L-type $\mathrm{Ca}^{2+}$ current in the pituitary cell line AtT-20. Neuroscience 71:1073-1081.

Talley EM, Lei Q, Sirois JE, Bayliss DA (2000) TASK-1, a two-pore domain $\mathrm{K}^{+}$channel, is modulated by multiple neurotransmitters in motoneurons. Neuron 25:399-410.

Toth PT, Bindokas VP, Bleakman D, Colmers WF, Miller RJ (1993) Mechanisms of presynaptic nerve terminals. Nature 364:635-639.

Turner JP, Salt TE (1998) Characterization of sensory and corticothalamic excitatory inputs to rat thalamocortical neurones in vitro. J Physiol (Lond) 510:829-843.

Turner TJ, Adams ME, Dunlap K (1993) Multiple $\mathrm{Ca}^{2+}$ channel types co-exist to regulate synaptosomal neurotransmitter release. Proc Natl Acad Sci USA 90:9518-9522.

Ulrich D, Huguenard JR (1996) Gamma-aminobutyric acid type B receptor-dependent burst-firing in thalamic neurons: a dynamic clamp study. Proc Natl Acad Sci USA 93:13245-13249.

Vezzani A, Sperk G, Colmers WF (1999) Neuropeptide Y: emerging evidence for a functional role in seizure modulation. Trends Neurosci 22:25-30.

Viana F, Hille B (1996) Modulation of high voltage-activated calcium channels by somatostatin in acutely isolated rat amygdaloid neurons. J Neurosci 16:6000-6011.

von Krosigk M, Bal T, McCormick DA (1993) Cellular mechanisms of a synchronized oscillation in the thalamus. Science 261:361-364.

Wagner JJ, Terman GW, Chavkin C (1993) Endogenous dynorphins inhibit excitatory neurotransmission and block LTP induction in the hippocampus. Nature 363:451-454.

Wang HL, Bogen C, Reisine T, Dichter M (1989) Somatostatin-14 and somatostatin-28 induce opposite effects on potassium currents in rat neocortical neurons. Proc Natl Acad Sci USA 86:9616-9620.

Weisskopf MG, Zalutsky RA, Nicoll RA (1993) The opioid peptide dynorphin mediates heterosynaptic depression of hippocampal mossy fibre synapses and modulates long-term potentiation. Nature 362:423-427.

White MG, Crumling MA, Meriney SD (1997) Developmental changes in calcium current pharmacology and somatostatin inhibition in chick parasympathetic neurons. J Neurosci 17:6302-6313.

Williams D (1953) A study of thalamic and cortical rhythms in petit mal. Brain 75:50-59.

Williams SH, Johnston D (1996) Actions of endogenous opioids on NMDA receptor-independent long-term potentiation in area CA3 of the hippocampus. J Neurosci 16:3652-3660.

Yamada M, Inanobe A, Kurachi Y (1998) G protein regulation of potassium ion channels. Pharmacol Rev 50:723-760.

Yawo H, Chuhma N (1993) Preferential inhibition of omega-conotoxinsensitive presynaptic $\mathrm{Ca}^{2+}$ channels by adenosine autoreceptors. $\mathrm{Na}$ ture 365:256-258. 